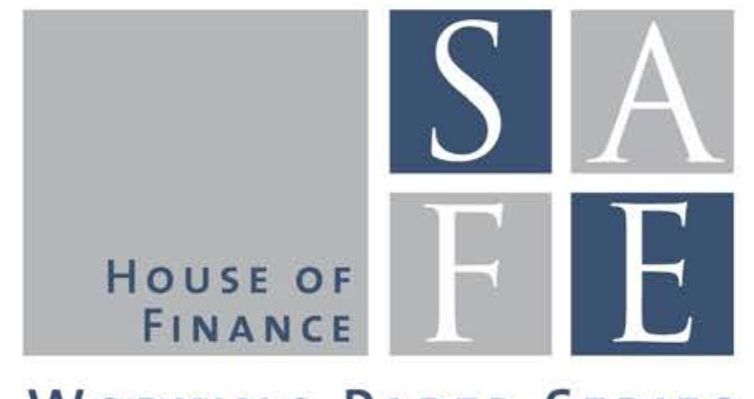

WORKING PAPER SERIES

Maddalena Davoli - Jia Hou

\title{
Financial Literacy and Socialist Education: Lessons from the German Reunification
}

SAFE Working Paper No. 217

SAFE I Sustainable Architecture for Finance in Europe A cooperation of the Center for Financial Studies and Goethe University Frankfurt 


\section{Non-Technical Summary}

The growing number of financial instruments available to households in their daily-life decisions has amplified the role of individuals' literacy in financial matters, by creating the need of a deeper understanding of economic and financial concepts in order to deal with pension plans, new credit products, wealth accumulation and so on.

A growing body of literature over the last decade, recognizing the importance of financial literacy, has focused on the study of determinants and consequences of different levels of financial ignorance, generally identifying a significantly negative effect of poor understanding of financial matters on household's financial behaviors and economic outcomes, such as portfolio choice, wealth accumulation and retirement planning. Hence, financial literacy has emerged in the last years as a valuable asset to individuals' wellbeing. Although a high heterogeneity in financial literacy exists across different population groups and specific sociodemographic characteristics, such as gender, age and educational level, the determinants of such different patterns are not clear.

Identifying such determinants is crucial to improving financial literacy for the broad population. Is it true that individuals' specific characteristics shape households understanding of financial literacy, or do institutions also play a role? This is what our analysis aims to understand.

It is quite complicated to identify the effect of institutions on individuals' outcomes: on the one hand, unobserved heterogeneity is always difficult to fully control for, and relevant factors are likely to be omitted in the estimation procedure; on the other hand, individuals' behavior and the institutional setting of a country are tightly related, making it difficult to understand the direction of causality. Financial literacy may be determined by specific institutional features within a country, but financially literate individuals could also contribute to shape the institutional framework in a specific direction.

To answer this question, this paper exploits the unique set-up of the German reunification, which provides an exogenous variation in the institutional setting of two countries. We particularly focus on one aspect of the institutional framework of pre-unified Germany, the educational system, to explain the heterogeneity in financial literacy scores across Germany. The exogenous division of Germany after the Second World War, the sharp differentiation of the educational systems and the subsequent reunification in 1990, which forced East Germany to quickly adapt to the political and educational structures of West Germany, represent a suitable quasi-natural 'experiment' to observe changes in the institutional set- tings of the German Democratic Republic (GDR), exogenous to other individual characteristics prior to the division.

We use a new household-level survey data, the German Panel on Households Finances (PHF), to analyze the different financial literacy scores registered across Germany and we employ three standard questions on interest rate, inflation and risk identification to construct an index of financial literacy for each survey respondent.

Exploiting the wide range of birth cohorts included in the data and the information on the region of residence in 1989, we analyze the financial literacy of cohorts with different lengths of exposure to different educational systems, prior to the reunification, and cohorts experiencing the same educational system, the one of Western Germany, after the reunification. The German reunification exogenously exposed Eastern households, some fully and some only partially, to a socialist educational system. Hence, by finding significant differences in financial knowledge between eastern households in schooling age in 1989 and other households, we can identify the effect of the socialist educational system on financial literacy.

We find that, in line with previous literature, variables capturing the socio-demographic and economic background of the respondents have the expected impact, but a consistent and 
significant gap between East and West Germany persists in the results. Among the determinants of financial literacy, education appears to be the factor that has the biggest positive effect, both in West and East Germany, and the one that may help the most in closing the gap between the two regions. However, we find evidence that the longer an Eastern household has been exposed to socialist education, the lower the financial literacy. This evidence points to a particularly important role of high school education in the former GDR in driving down financial literacy scores in 2014.

Our finding that socialist education affected current levels of households financial literacy points at a long-lasting effect of institutions. Households raised with socialist values experience a deep impact of such upbringing on their life-outcomes, even 25 years after the reunification. 


\title{
Financial Literacy and Socialist Education: Lessons from the German Reunification *
}

\author{
Maddalena Davoli ${ }^{\dagger} \&$ Jia Hou ${ }^{\ddagger}$
}

\begin{abstract}
A growing body of literature shows the importance of financial literacy in households' financial decisions. However, fewer studies focus on understanding the determinants of financial literacy. Our paper fills this gap by analyzing a specific determinant, the educational system, to explain the heterogeneity in financial literacy scores across Germany. We suggest that the lower financial literacy observed in East Germany is partially caused by a different institutional framework experienced during the Cold War, more specifically, by the socialist educational system of the GDR which affected specific cohorts of individuals. By exploiting the unique set-up of the German reunification, we identify education as a channel through which institutions and financial literacy are related in the German context.
\end{abstract}

Keywords: financial literacy determinants, socialist education, German reunification, DiD

\footnotetext{
${ }^{*}$ We are grateful to the LOEWE Center for Sustainable Architecture for Finance in Europe (SAFE) program for financial support to our research. We than the Deutsche Bundesbank allows us to access to the PHF dataset. We wish to thank Michael Berlemann, Kristof De Witte, Horst Entorf, Nghiem Giang, Cahit Guven, Majlinda Joxhe, Lennart Kraft, Jorge Quintana, Jan Schnellenbach and Seonho Shin for suggestions and comments. We are also grateful to participants at the joint SAFE-Bundesbank seminar, where earlier results were presented. We wish to thank all the participants in the $11^{t h}$ Workshop of Political Economy (Dresden), the Equity in Education Workshop (KU Leuven) and the $4^{\text {th }}$ Annual Workshop on Natural Experiments in History (Deakin Melbourne), the $6^{\text {th }}$ Luxembourg Workshop on Household Finance and Consumption (Luxembourg).

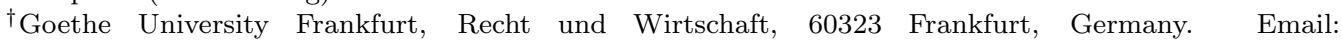
davoli@wiwi.uni-frankfurt.de.

${ }^{\ddagger}$ Goethe University Frankfurt, House of Finance, 60323 Frankfurt, Germany. Email: hou@safe.unifrankfurt.de
} 


\section{Introduction}

Increasingly complex pension plans, credit products and financial services have amplified the role of individuals' literacy in financial matters. Because of the growing number of financial instruments readily available to households in their daily life decisions, it comes as no surprise that scholars and policy makers pay much attention to financial literacy. Early initiatives of the OECD (OECD (2012)), followed by national surveys and training programs sponsored by the World Bank among others, have registered a sizable low level of financial knowledge around the world, especially in specific subgroups of the population. Parallel to that, there is evidence of financial ignorance highly correlated with and affecting poor financial behavior at the individual level (see Lusardi and Mitchell (2014), among others).

Despite the importance of the topic and the quite heterogeneous variation in financial literacy levels within and across countries, few studies have successfully explained the origin of such different degrees of understanding of financial matters. We contribute to this topic by analyzing the East-West German gap in financial literacy. The difference in financial literacy scores between East and West Germany are not a new finding, as reported by Bucher-Koenen and Lamla (2014), and these have been proven to impact decisions related to retirement planning (Bucher-Koenen and Lusardi $(2011))$. The reason for such a gap, however, is not clear. Our hypothesis, empirically tested with a Bundesbank collected household survey, is that financial literacy levels are determined both by the standard set of household/individual's characteristics and by the institutional features of a country, more specifically by the characteristics of the educational system. We exploit the unique set-up of the German reunification, which provides an exogenous variation in the institutional setting of two countries by forcing the Eastern state to quickly adapt to the political and economic structure of the West Germany.

The claim we make is that the institutional frameworks in place in the German Democratic Republic (GDR) and Federal Republic of Germany (FDR) from 1949 to 1990 provided different incentives to acquire financial education at the individual level, affecting the current gap between East and West Germany. Fuchs-Schündeln and Masella (2016) are the first to suggest that socialist education has long-term consequences on different economic outcomes at the individual level. In line with their analysis, we claim that the inequality between financial literacy scores cannot only be attributed to a geographical heterogeneity within Germany, but to a different institutional framework, which reflected on the educational system of the GDR and thus, on the possibility of acquiring financial education at the individual level. Hence, we identify education to be the channel through which institutions and financial literacy are related in this specific context. 
Our identification strategy consists in comparing financial literacy of those who lived and got educated in East Germany to a control group who always lived in the West or who lived in the East but were too young to be affected by the socialist education before the reunification. If the gap in financial literacy between the older Eastern/Western cohorts is significantly different from the gap between the younger Eastern/Western cohorts, we attribute it to the effects of institutional settings before the reunification. We exploit the information of residence in 1989 to proxy the location where individuals receive education to investigate whether there exists a significant difference in financial knowledge for those households living in the East in school age in 1989, as compared to others. In particular, individuals born in 1977 or earlier, in East Germany, were old enough to to exposed to education under the socialist regime, and represent the group of treated individuals. Those born afterwards in the East (hence, too young), as well as all the West Germany households, were not exposed (or only partially) to socialist education because of the exogenous shock of reunification.

The contribution of the paper is twofold. First, we employ a quite unexploited dataset, the Panel Household Finances, part of a wider European project coordinated by the European Central Bank on household finances. To our knowledge, no work on the determinants of financial literacy has been done yet on the use of PHF data. The data commonly used for the case of Germany are collected by SAVE, which is much smaller in sample size and over-weighted for older cohorts as compared to PHF. Secondly, we try to provide an explanation for an already documented gap between East and West Germany, by exploiting the exogenous variation in the institutional (and educational) framework of East Germany following the fall of the Berlin Wall.

We find that, in line with previous literature, variables capturing the socio-demographic and economic background of the respondents have the expected impact, but a consistent gap in the estimates between East and West Germany exists in the results. Among the determinants of financial literacy, education appears to be the factor that has the biggest positive effect, both in West and East Germany, and the one that may help the most in closing the gap between the two regions. Finally, we find evidence that the institutional setting of Germany, reflecting onto the educational system, plays a role in explaining the East/West financial literacy gap.

The rest of the paper is structured as follows: Section 2 briefly reviews the different strands of literature related to our paper. Section 3 describes the dataset and presents descriptive results. 4 presents the empirical results. We first show the benchmark results using the standard methodology as in the literature. After a more detailed discussion on 
our identification strategy, we present the main estimation results, in the attempt to explain regional differences in financial literacy levels across Germany. Section 5 concludes.

\section{Literature Review}

Our study is nested into three different lines of the existing literature. The first one is about the consequences of financial literacy. The path-breaking initiative from Lusardi and Mitchell in 2004, which introduces for the first time a financial literacy module in the U.S. Health and Retirement Study, opens the path to a financial literacy literature. From then on, a growing body of studies have been analyzing costs, benefits and consequences of different levels of financial knowledge across various segments of the population. The questions written by Lusardi and Mitchell back the development of a uniform way of assessing financial literacy, based on an index that tests individuals' knowledge about inflation, compound interest and risk diversification. The basic questions have been further developed by scholars such as Rooij et al. (2011), adding new items in order to capture more complicated aspects of individuals' financial sophistication 1

Several studies show financial literacy correlated with a wide array of financial behaviors and outcomes ${ }^{2}$ Bernheim et al. (2001), exploiting the exogenous variation in financial curricula across U.S. and over time, find a link between exposure to financial information and savings. In more recent works, Behrman et al. (2012), Bernheim and Garrett (2003) and Lusardi and Mitchell (2007) suggest, quite robustly, the existence of a causal relationship between financial literacy and assets or wealth accumulation in different countries. Also Jappelli and Padula (2013) predict, both theoretically and empirically, a correlation between wealth and portfolio allocation choices and the individual stock of financial knowledge. Rooij et al. (2011) show a link between literacy and stock market participation in a Dutch survey, employing a broader set of questions on financial sophistication as compared to the classical three-questions approach from Lusardi and Mitchell (2004). Further, a higher degree of retirement planning is found among households with higher financial literacy (Lusardi and Mitchell (2007) and Fornero and Monticone (2011) ) and these results are consistent with those of Bucher-Koenen and Lusardi (2011) on East Germany, especially for households with low education and low income. For a detailed survey of poor financial behaviors associated with low levels of financial literacy, such as mortgage decisions, personal debt and portfolio diversification, see Lusardi and Mitchell (2014)

\footnotetext{
${ }^{1}$ Please see Lusardi and Mitchell (2014) and Hastings et al. (2013) for more exhaustive reviews on the measurement of financial literacy.

${ }^{2}$ See Cole et al. (2016) and Gustman et al. (2012) for an alternative position on the topic.

${ }^{3} \mathrm{See} \mathrm{Xu}$ and Zia (2012) among others, for an overview of the issue around the world. Note, as well, that there is a growing body of experimental evidence on the causal effect of financial literacy on financial behavior. See, Brugiavini et al. (2015), among others.
} 
A second line of research relates to the determinants of financial literacy. In spite of the increasing body of research on correlations between financial literacy and financial behavior, evidence on the determinants of financial literacy inequalities are still scarce. Current theories on the accumulation of financial literacy propose a production function for financial literacy (Delavande et al. (2008)) or a framework where financial literacy is an endogenous variable (Jappelli and Padula (2013), Lusardi et al. (2017)), dependent on the cost and return of it.

While the exact accumulation process of financial literacy is not clear yet, empirical studies show a number of correlations between financial knowledge and specific socio-economic and demographic characteristics. In general, women exhibit lower levels of financial literacy (Lusardi and Mitchell (2008)), and this is consistently true regardless of the marital status and the country considered (Xu and Zia (2012)). Even though it is quite difficult to disentangle age effects from cohort effects in cross-sectional studies, Lusardi and Mitchell (2014) notice that financial literacy follows an inverted U-shape with respect to age, with the youngest and the elderly ones having lower literacy rates. Chen and Volpe (1998) and Chen and Volpe (2002) argue that education and experience have an important impact on the financial literacy of younger population. Other variables taken into consideration are wealth, marital status, number of children and employment (Rooij et al. (2011)). Brown et al. (2018) find that cultural differences drive the heterogeneity in financial literacy between German-speaking and French-speaking students within Switzerland.

The existing evidence shows generally low levels of financial literacy, which are consistently so across population groups and surveys. But in most cases only descriptive results are available. The challenges to identify financial literacy determinants are related to the presence of unobservable factors, such as cognitive or mathematical ability, and to the existence of possible reverse causality, which can bias the estimation results and make it difficult to claim the existence of a causal link (Behrman et al. (2012)).

Finally, our work relates to analysis on long-lasting effects of communism on economic outcomes and, more specifically, on the effects of German reunification on individual outcomes. The international comparison of economic literacy by Jappelli (2010) suggests how more developed financial markets provide incentives to acquire financial knowledge and this fact is at the root of the lower literacy registered in former socialist countries. East and West Germany are found to differ on a variety of aspects, and many studies look for causal links between such differences and the divergent socio-economic framework experienced by the two regions for over 40 years. Fuchs-Schündeln and Haliassos (2015) report a different 
degree of product participation among the two areas, and exploit the quasi-experiment of reunification to assess the impact of availability of new and unfamiliar products on Eastern citizens participation. Among others, Bonin and Euwals (2002) focus on the effect of reunification on different rates of women labor force participation, Fuchs-Schündeln and Schündeln (2015) on political preferences and Brosig-Koch et al. (2011) on solidarity behavior.

Our paper is most closely related to Fuchs-Schündeln and Masella (2016) and BucherKoenen and Lamla (2014). Fuchs-Schündeln and Masella (2016) analyze how different length of exposure to socialist education affected long-term labor market outcomes of Eastern Germans. They find that the exposure decreases the probability of obtaining a college degree. The latter paper, also exploiting the exogeneity of German reunification, investigates the determinants of financial literacy. The authors find a significant gap in financial literacy between East and West, the gap which remains mostly unexplained once they include in the model a broad set of control variables and perform a Blinder-Oaxaca decomposition. We can improve on their analysis by employing a nationally representative dataset, the Bundesbank Panel Household Finance, which includes more observations and a broader range of cohorts exposed to the treatment of German reunification. This, together with the information on households' residence in 1989, allows us to increase the precision of the estimates and to better define the identification strategy.

\section{The Data}

Before describing the data, a short introduction of the German historical and political framework is provided. We present, then, the first descriptive results and some general findings about the dataset on financial literacy.

\subsection{Historical Background}

In the period between 1949 and 1990, Germany was divided in two states, as a result of the post World War II occupation. One in the East, the German Democratic Republic (GDR), characterized by a planned economy and a socialist political regime, and the other in the West of Germany, the Federal Republic of Germany (FRG), characterized by a market economy and a democratic political structure. The two regions shared a common cultural and political-economic heritage, up to the end of World War II. They experienced for the subsequent 40 years radically different socio-economic paths, and were, then, unified again in the 1990s, with the East quickly adopting the Western socio-economic and political structures. The event of the reunification following the Berlin Wall Fall represents an interesting exogenous shock to the institutional and political setting of East Germany, as this part of the country was forcibly assimilated to the West German system. 
The reform of the educational system was one of the many reforms experienced by the East shortly after the reunification, and consisted in the Eastern system adopting the main features of the Western schools. According to Fuchs-Schündeln and Masella (2016), after the Berlin Wall fall in November 1989, the educational system in the GDR was rapidly transformed, especially through the immediate removal of the socialist content of the curricula. The changes in the system were affecting both the structure of the schools and the content of the programs, as well as other aspects.

As summarized by Fuchs-Schündeln and Masella (2016), there were some crucial differences in curricula between the two former regions of Germany The GDR allocated more than $10 \%$ of school time to socialist education, which, in our hypothesis, may be detrimental to financial literacy. However, also the teaching time allocated to mathematics and natural sciences was higher, as compared to the FDR. Those subjects, numeracy especially, have been proven to positively correlate with financial literacy outcomes. For example, mathematical ability might improve people's understanding of compound interest rate, since it requires the ability of calculation (see Hung et al. (2009) and Lusardi (2012)).

Moreover, the pre-1990 East was not adopting a tracking system, as opposed to West Germany, where students were stratified into different schools according to their early-school achievement levels. Compulsory schooling was lasting 10 years in the GDR, the so-called Polytechnische Oberschule (see Figure 5), period after which students could access higher educational tracks, like universities, or applied studies, combining hours of education and apprenticeships. However, the acceptance criteria into apprenticeships or higher education were centrally planned and not necessarily based on academic merits (Marsh et al. (2001)). In addition, there was a clear goal in the East German system to support the formation of a so-called socialist personality (allseits entwickelte sozialistische Persönlichkeit), giving importance not to individuals' ability levels, rather to overcoming disparities across individuals through unitary and highly centralized teaching strategies and curricula (Marsh et al. (2001)).

\subsection{The Panel Household Finances Survey}

The dataset consists of the nationally representative 2010 and 2014 waves of the PHF (Panel Household Finances), a new household level survey conducted by the Deutsche Bundesbank. The survey covers information on balance sheets, pensions, income, work-life and other households' demographic characteristics and it was collected as an integral part of

\footnotetext{
${ }^{4}$ See Figure 1 in Fuchs-Schündeln and Masella (2016) for a graphical representation of the differences in curricula.
} 
the Household Finance and Consumption Survey (HFCS), taking place in all Euro areas countrie: 5

In order to exploit the most recent information on financial literacy patterns in Germany, the main sample employed in our empirical analysis consists of all households from the second wave, for a total of 4,461 observations ${ }^{6}$. Because we are interested in the effects of different education system before the reunification in 1989, we remove from the sample all observations who arrived in Germany after this year, about $5 \%$ of the total sample.

The PHF dataset is characterized by a stratified multi-stage sampling design method, and, unless otherwise stated, we employ survey weights in order to adjust the oversampling of wealthy households and to get consistent inference for the whole population. Moreover, to mitigate issues related to missing responses, an iterative multiple imputation (MI) procedure is used in the PHF survey. More specifically, five multiple imputed datasets are generated following Rubin's method (Rubin (1987), Rubin (1996)). We include all five imputed datasets for our descriptive results, so to increase the efficiency of the analysis. But in the empirical section we exclusively employ the first set of imputations, since very few values were missing for our variables of interest7 (Appendix Table A1 presents the number of missing and imputed observations for the key variables).

As of now, the PHF is the biggest and most comprehensive households finance survey in Germany, which allows us to check both cross-sectional and time dimensional evidence of financial literacy drivers.

\subsection{Measures of Financial Literacy}

The PHF includes the three standard financial literacy questions, first used in the U.S. 2004 Health and Retirement Study (HRS). This set of questions has been widely used in national and international surveys to investigate household financial literacy, e.g., U.S. 2007 - 2008 National Longitudinal Survey of Youth. The information has been collected exclusively from the financial knowledgeable person (FKP in the following) at the household level.

The three questions are as follows:

\footnotetext{
${ }^{5}$ For more detailed information on PHF dataset, see: ww. bundesbank.de/Navigation/EN/Bundesbank/ Research/Panel_on_household_finances/panel_on_household_finances.html

'The German PHF' survey has a large panel component: all households are re-contacted, all individuals tracked, split households are taken into accounts. About 2, 300 households participated in both waves

${ }^{7}$ Results are not qualitatively different when we make use of the other imputed datasets, or when we perform the analysis using the "mi estimate" command in STATA. Results are available upon request.
} 
- Let us assume you have a balance of $€ 100$ in your savings account. This balance bears interest at an annual rate of $2 \%$, and you leave it there for 5 years. What do you think: how high is your balance after 5 years? [Higher than $€ 102$; Exactly $€ 102$; Lower than $€ 102$.

- Let us assume that the interest paid on your savings account is $1 \%$ per year and the inflation rate is $2 \%$ per year. What do you think: After a year, will you be able to buy just as much, more or less than today with the balance in your savings account? [More; Just as much; Less than today.]

- Do you agree with the following statement: "The investment in the stock of a single company is less risky than investing in a fund with stock in similar companies"? [I agree; I do not agree.]

Table 1 below reports the financial literacy patterns in Germany for the sample of interest described above, as well as for households in the first wave, separately. 


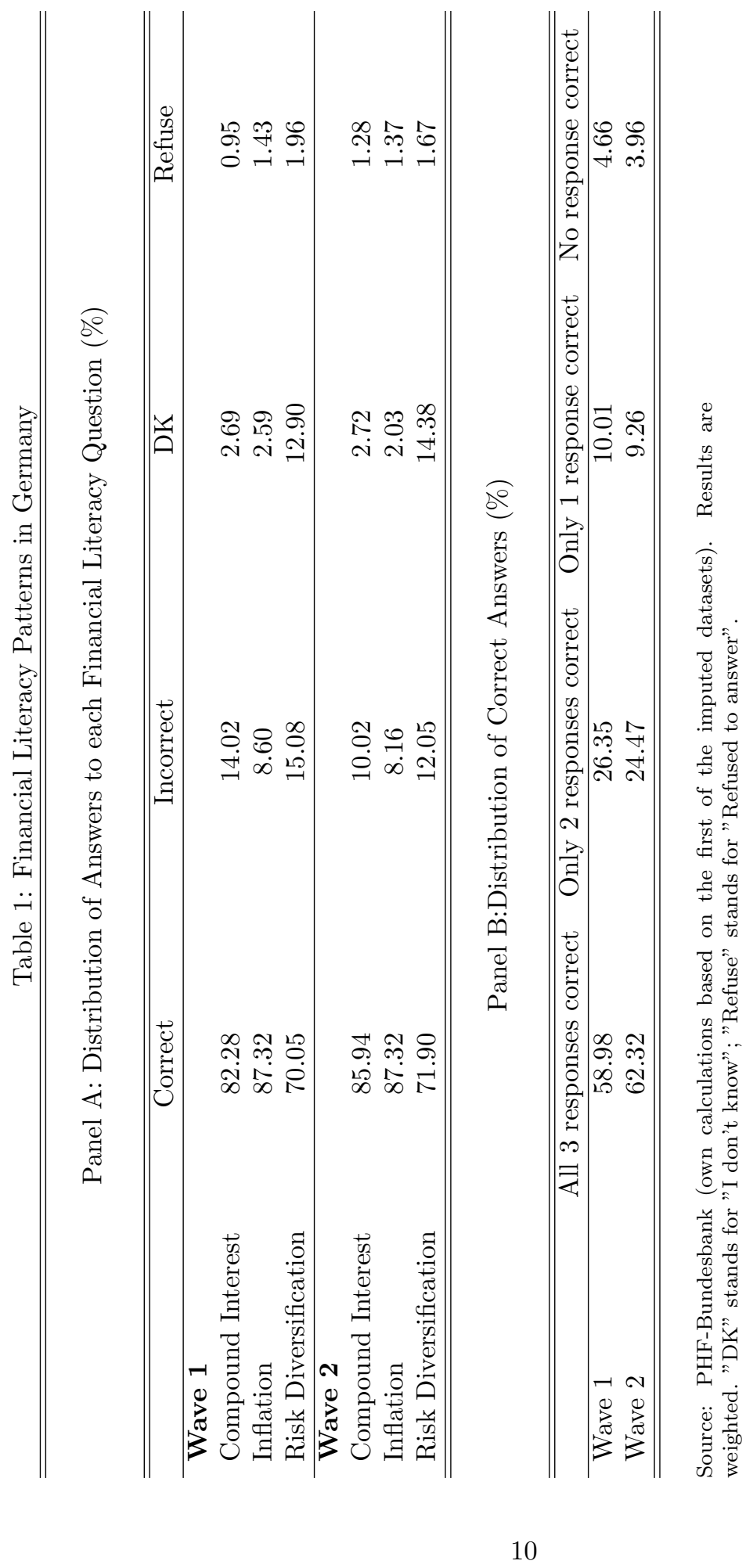


We observe higher levels of financial literacy for the 2014 wave, compared to those resulting from Bucher-Koenen and Lusardi (2011) in 2009 SAVE dataset. There, the correct answer ratio for the questions of compound interest, inflation and risk diversification is $82.4 \%, 78.4 \%$ and $61.8 \%$ respectively, while here we see $84.01 \%, 87.43 \%, 70.39 \%$, correspondingly. The $2010-2011$ wave also points at higher financial literacy, especially on risk diversification, than the one in Bucher-Koenen and Lusardi (2011). Overall, financial literacy levels for German households are quite high when we compare them with other countries 8 . At the disaggregated level, the ratio of correct answers to the compound interest question increases by $3.66 \%$ across waves, and to the risk diversification question by a moderate magnitude of $1.85 \%$.

Panel B shows the distribution of correct answers: The share of households answering all three questions correctly increases by about $3.3 \%$ across waves and the question on compound interest rate is the one which contributes the most to such improvement. In spite of almost a $2.0 \%$ increase from wave 1 to wave 2, the ratio of FKP who can answer the risk diversification question correctly is the lowest among the three questions.

We define an individual as financially literate when she answers all three questions correctly. In line with other studies on the topic (see, e.g., Bucher-Koenen and Lusardi (2011) Lusardi and Mitchell (2008)), we employ a dummy to capture such information, the main dependent variable in our paper.

We implement a Cronbach's $\alpha$ test to examine the internal consistency of our financial literacy measure9 and we find our index to have a modest reliability, with an estimated correlation of about 0.775 . The item-test correlation is similar for the three financial literacy questions and we find that removing any of the items from the index would make our scale less reliable, which is an argument for keeping all current items in our index.

\subsection{A Glance at the West/East Divide in Financial Literacy}

The survey questions on individual's residence in 1989 and at the time of the survey allow us to track where, in Germany, the financially knowledgeable person grew up and, likely, got education from. Figure 1 and the descriptive results in the Appendix A2 underline the existence of a regional divide in financial literacy patterns. Households living in West Germany exhibit a consistently higher correct-answers-rate over the two waves, even though this discrepancy decreases over time. The only exception is represented by the answer to the

\footnotetext{
${ }^{8}$ See, among others, Agnew et al. (2013) for Australia, Sekita (2011) for Japan, Lusardi and Mitchell (2011) for USA. Table 2 of Hastings et al. (2013) present a summary table on financial literacy around the world

${ }^{9}$ Results available upon request.
} 
risk diversification question, where East German households perform better in both waves.

Figure 1: Financial Literacy by Residential Location

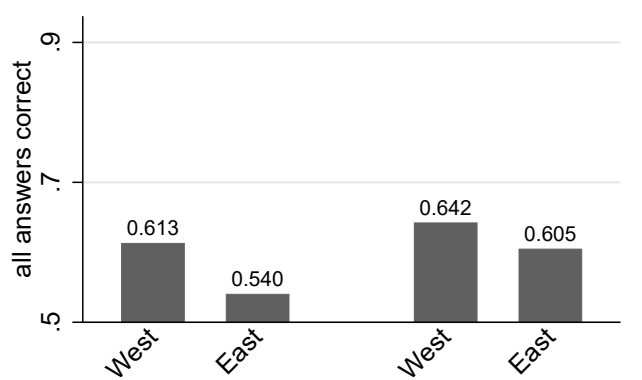

Wave 1

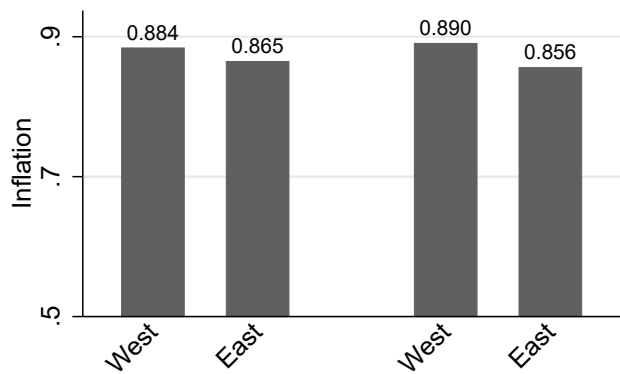

Wave 1

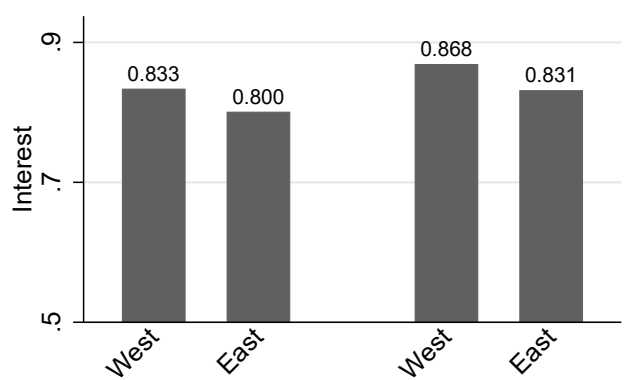

Wave 1

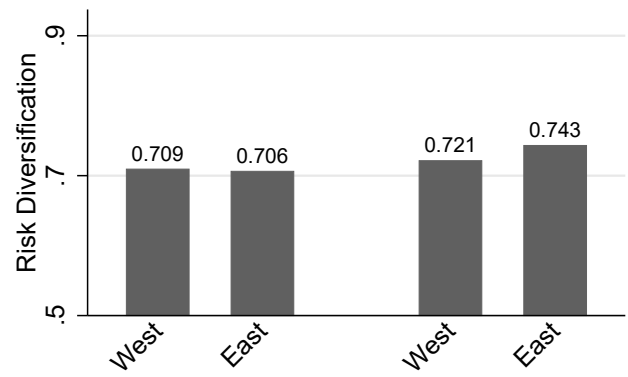

Wave 1
Wave 2

Wave 2

Source: PHF-Bundesbank (own calculations based on the first set of the imputed datasets). Results are weighted.

The bar represents for the share of population who answered the respective financial literacy question correctly in the given time. The residence information is based on the current residence of the household at the time of survey. We drop those observations who were not resident in Germany in 1989, which account for $5 \%$ of the sample. The first figure reports the percentage of households answering all questions correctly, the remaining three reports the three questions at a disaggregated level. Data are weighted and only the first set of imputed data has been taken into account.

The generally higher correct-response ratio to the inflation question might be caused by the fact that inflation affects households' daily life more poignantly. The low improvement from wave 1 to wave 2 possibly indicates an impact of the low inflation rates in Germany between 2010 and 2014 10 Households living in East Germany have a higher ratio of correct answers for the risk diversification item, possibly because of their greater exposure to the

\footnotetext{
${ }^{10}$ During this period, the highest annual inflation rate of Germany is $2.04 \%$ in 2012 , while $3.29 \%$ in Italy in 2011, and $2.47 \%$ in France in 2011. Source: http://www.inflation.eu/inflation-rates/germany/ historic-inflation/cpi-inflation-germany.aspx
} 
economic shock of reunification and their more conservative attitude towards risks due to historical reasons 11 . Note, however, that East-West financial literacy differences are not statistically significant, when using current residence as a relevant variable.

Figure 2 shows clear differences in the gap between East and West across different cohorts. We use the first wave of data to draw the figure, as it can provide us with more intuition. In line with previous findings (see Xu and Zia (2012) for an overview), both regions exhibit an inverted U-shape of financial literacy scores with respect to age, but the gap between East and West appears to be wider for the age group around 40. Younger and older households are less -or not at all- exposed to a different educational systems during the Cold War, while the age group 36 to 50, indeed, is made by those households who fully complete their schooling in the divided country. Hence, Figure 2 suggests, at least from a descriptive perspective, a positive impact of the unified educational system.

Table A2 in the Appendix reports summary statistics of the East/West divide in financial literacy over other individual characteristics. West Germany scores better than East Germany over some of the employment variables, while middle-level education seems to be a stronger predictor of financial literacy in the East and higher level education is a stronger predictor of financial literacy in the West.

\footnotetext{
${ }^{11}$ However, Fuchs-Schündeln and Schündeln (2005) suggest a higher degree of risk aversion among civil servants in the West than in the East, mainly due to the low labor income risk in the former GDR (pp1087, pp1101).
} 
Figure 2: Financial Literacy Over Age

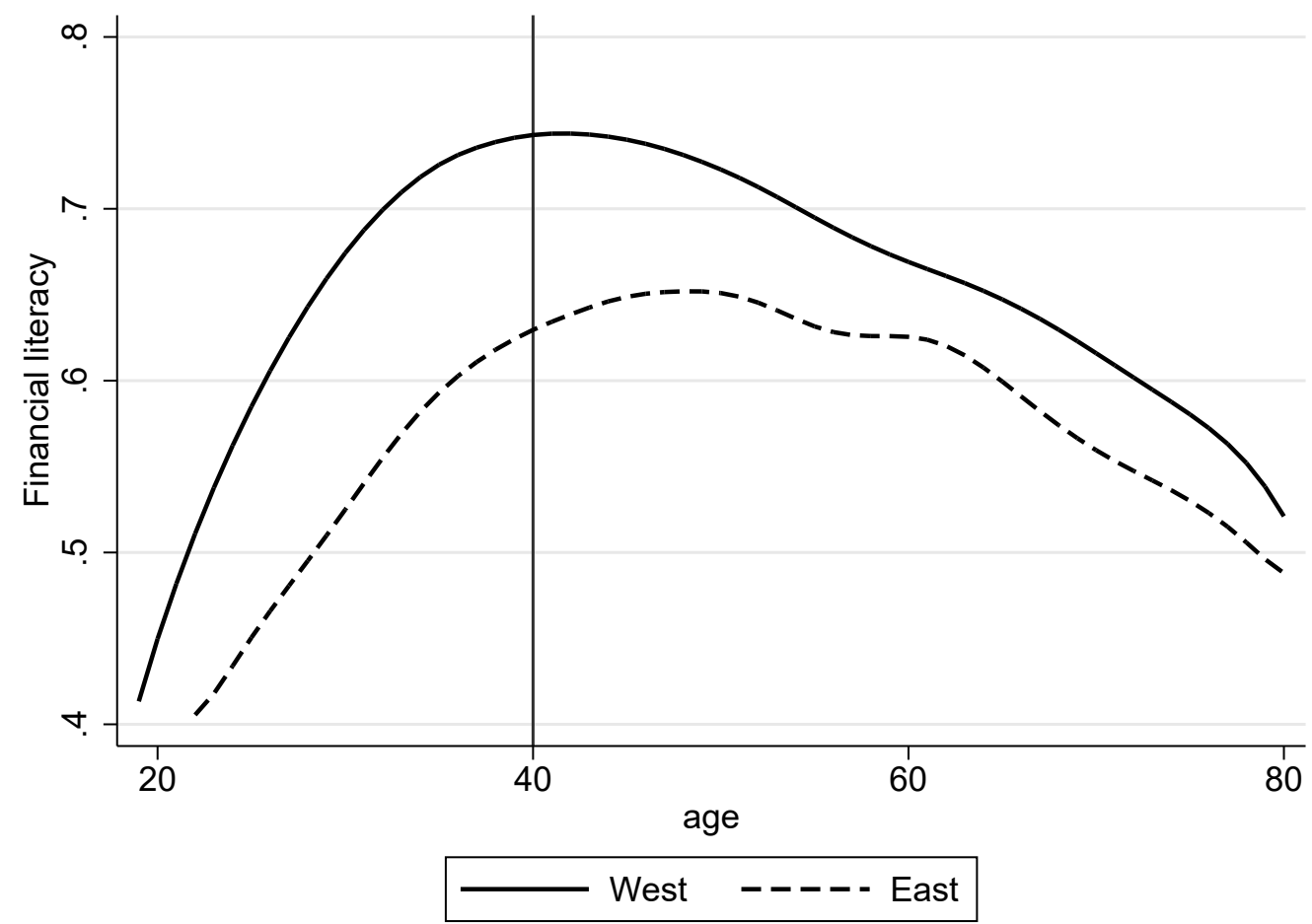

Source: PHF-Bundesbank (own calculations based on the first of the imputed datasets). Results are weighted.

The first wave of the PHF dataset is employed. Residence refers to respondents' residence at the time of survey. The figure is smoothed by lowess filter. 


\section{Empirical Evidence}

It is often hard to disentangle different drivers of financial literacy from each other, because of the endogeneity of many socio-economic individual-level variables. In our analysis, living in East or West Germany at the present time is clearly an individual choice, determined by and related to many other individual characteristics that we are not able to control for in our analysis and possibly affect financial literacy scores. The German reunification, however, can be seen as an event exogenous to financial literacy, since it was not affected or caused by the financial literacy of people back to that time. Following such event, East Germany underwent radical changes and was exposed to a series of political and institutional reforms, which mainly consisted in the adoption of West Germany institutions (Bucher-Koenen and Lamla (2014)).

Given the descriptive evidence in Section 3 about the East/West divide in financial literacy, we first try to identify whether residence in 1989 is a significant correlate of financial literacy scores, and how do other individual-level determinants differ by region of residence at the time of the Berlin Wall Fall. We employ Probit as our main empirical model, following Lusardi et al. (2010) among others, but we also implement Linear Probability Model and/or Logit for comparison whenever possible. Then, we implement a difference-in-differences type of strategy in order to check more specifically the role played by different educational systems. In the robustness check we investigate further how stable the effect of regional division is.

Our main dependent variable is a dummy for answering all three questions correctly, and estimations for disaggregated measure of financial literacy are selectively reported, whenever necessary to provide further insights. In the DID approach and robustness check we focus on the aggregate measure of financial literacy.

As mentioned in the previous section, our results are based on the second wave sample and we only report regression results from using one of the five imputed data sets. However, results are consistent when using $\mathrm{MI}$ estimate methods 12 .

\subsection{The East/West Divide in Financial Literacy: A Benchmark}

Following Lusardi et al. (2010), our baseline model is a Probit model, allowing us to capture the binary response design of the financial literacy index. For the sake of completeness,

\footnotetext{
${ }^{12} \mathrm{MI}$ estimation considers all five imputed data sets. As there are not many missing values for the key variables in our analysis (see Table A1, results do not vary in a sensible manner.
} 
we also report results from OLS and/or Logit, whenever applicable. Our model is as follows:

$$
\begin{gathered}
y_{i}^{*}=\boldsymbol{X}_{\boldsymbol{i}} \boldsymbol{\beta}+\epsilon_{i}, \quad y_{i}= \begin{cases}1 & \text { if } y_{i}^{*}>0 \\
0 & \text { otherwise }\end{cases} \\
P(y=1 \mid \mathbf{X})=\Phi\left(\boldsymbol{X}_{\boldsymbol{i}}^{\boldsymbol{T}} \boldsymbol{\beta}\right),
\end{gathered}
$$

where $\boldsymbol{X}_{\boldsymbol{i}} \boldsymbol{\beta}=\alpha+\sum_{k=1}^{K} \beta_{k} X_{k i}+\epsilon_{i}$, and $\Phi$ is the cumulative distribution function (CDF) of the standard normal distribution. The parameters are estimated by maximum likelihood. If the independent variable is binary, as it is the case for the residence location dummy East, the effect of a 0 to 1 change in $x_{j i}$ on the probability of success, i.e. the probability of correctly answering one or more of the financial literacy questions, is given by

$$
\Phi\left(\alpha+\beta_{1} \bar{x}_{1 i}+\beta_{2} \bar{x}_{2 i}+\ldots \beta_{j} * 1+\beta_{k} \bar{x}_{k i}\right)-\Phi\left(\alpha+\beta_{1} \bar{x}_{1 i}+\beta_{2} \bar{x}_{2 i}+\ldots \beta_{j} * 0+\beta_{k} \bar{x}_{k i}\right) .
$$

As revealed by previous studies, the main set of financial literacy determinants includes socio-demographic characteristics, such as age, gender, marital status and education, preference parameters, such as risk preferences, and economic-related variables, such as employment status. We first include all possible determinants but only report the estimated effect of residence in the East (at the time of the survey) on financial literacy in Table 2 Appendix Table A4 reports the estimated coefficients for a complete set of regressors. In order to provide an overview of the impact of residence in the East, we consider all five possible dependent variables, that is, the number of correct answers, a dummy for answering all financial literacy questions correctly, a dummy for answering the compound interest rate question (FL1), the inflation question (FL2) and the risk diversification question (FL3) correctly, respectively.

As can be seen in Table 2, current residence in the East significantly affects the knowledge of inflation (FL2) and risk diversification (FL3), but not interest rate (FL1). More specifically, residence in the East decreases respondent's knowledge on inflation while increases respondent's knowledge on risk diversification. At the aggregate level, current residence has no significant effect on financial literacy. It is possible that households exposed to different environment divert their attention to different aspects of financial literacy, while at the aggregated level the differences in single items compensate each other.

Unlike results displayed in Table 3 of Bucher-Koenen and Lamla (2014), being an Eastern resident does not always significantly correlate with financial literacy levels. However, the R-squared obtained from the OLS regression model lie in the range of $10 \%$ to $18 \%$, quite comparable to those obtained by Bucher-Koenen and Lamla (2014). Results are presented 
after controlling for migration between East and West Germany (we employ a dummy variable which equals one for the FKP who moved from East to West, or vice-versa, between 1989 and the time of the survey).

As many of the conventional regressors are not significant in determining financial literacy in our study, we decide to discard several of them in subsequent estimations. First, economic variables, such as measures for income, savings and loans, are dropped, in order to avoid "bad controls" issues (see Angrist and Pischke (2008) for a detailed discussion). Furthermore, the preference parameters and some other demographic characteristics are ignored, since they have a negligible impact both in quantitative and qualitative terms in our exploratory regression presented in Table A4

Table 2: The Effect of Residence in the East in 2014 on Financial Literacy

\begin{tabular}{|c|c|c|c|c|c|}
\hline & (1) & $(2)$ & (3) & (4) & $(5)$ \\
\hline & Joint & All Correct & FL1 & FL2 & FL3 \\
\hline \multirow[t]{2}{*}{ OLS } & -0.025 & -0.017 & -0.026 & $-0.047^{* *}$ & $0.048^{*}$ \\
\hline & $(-0.537)$ & $(-0.586)$ & $(-1.108)$ & $(-2.154)$ & $(1.753)$ \\
\hline \multirow[t]{2}{*}{ Logit } & 0.001 & -0.015 & -0.021 & $-0.039^{* *}$ & $0.053^{* *}$ \\
\hline & $(0.398)$ & $(-0.479)$ & $(-1.054)$ & $(-2.052)$ & 1.972) \\
\hline \multirow[t]{2}{*}{ Probit } & 0.001 & -0.017 & -0.023 & $-0.041^{* *}$ & $0.053^{*}$ \\
\hline & $(0.317)$ & $(-0.546)$ & $(-1.100)$ & $(-2.078)$ & $(1.952)$ \\
\hline $\mathrm{N}$ & 4111 & 4111 & 4111 & 4111 & 4111 \\
\hline R2(For OLS) & 0.181 & 0.139 & 0.108 & 0.092 & 0.120 \\
\hline \multicolumn{6}{|c|}{$\begin{array}{l}t \text { statistics in parentheses. }{ }^{*} p<0.1,{ }^{* *} p<0.05,{ }^{* * *} p<0.01 . \\
\text { Source: PHF-Bundesbank (own calculations based on the first of the imputed datasets } \\
\text { for the second wave). } \\
\text { "Joint" indicates the number of correct answers to the three FL questions. "All Cor- } \\
\text { rect" indicates whether the respondent answers all the three FL questions correctly or } \\
\text { not. FL1-3 indicates correct answer to the question of compound interest rate, infla- } \\
\text { tion and risk diversification respectively. All regressors from Table A4 are included. } \\
\text { Marginal effects at the mean are reported for the Logit/Probit model. From the initial } \\
\text { sample we drop all households who were not resident in Germany in } 1989 \text { ( } 5 \% \text { of the } \\
\text { whole sample), for a total of } 4,113 \text { observations. There are } 2 \text { further missing values } \\
\text { for log of income, which cause the two FKP to be dropped from the sample for the } \\
\text { regression. }\end{array}$} \\
\hline
\end{tabular}

Clearly, current residence itself cannot capture the complete picture of the regional divide in financial literacy. Looking at the determinants of financial literacy by East/West will help us to check further which factors might be regionally dependent. Table 3 presents the East/West divide in financial literacy determinant: 13 more specifically, the marginal effects on selected determinants from Probit model. As can be seen, a few determinants, including gender and education, have consistently significant effects on all measures of financial literacy across East and West. Being a female will in general decrease the household's financial

\footnotetext{
${ }^{13}$ Summary statistic on the selected key variables are given in the Appendix Table A3
} 
literacy, while different levels of education will always increase it. Also respondents' age is highly correlated with financial literacy, both in the East and in the West; being selfemployed generally has a positive effect, while being unemployed a negative on ${ }^{14}$

Due to the non-linear feature of the Probit model, it is hard to compare the significance of differences across groups, hence, we report the significance of the mean differences between West and East in Table A5 from OLS estimation for the aggregated level of financial literacy ${ }^{15}$. We observe that age, gender, middle-level secondary school, and being unemployed play very different roles in driving financial literacy scores in East and West Germany.

Among all covariates shown in Table 3 , education always plays a relevant positive role: the overall effect is partially offset when we look at the aggregate measure of financial literacy, but it is otherwise always significant for the three disaggregate items. Also, the magnitude of the estimates in the East is generally bigger than in the West for the questions concerning compound interest rate (FL1) and inflation (FL2). We see different explanations to this fact. It is possible that regional differences in the educational system exists and they are responsible of the different role played by each educational level in the two regions. An alternative explanation would be that the gap between the two regions could have been even bigger at the time before reunification and before the large impact of institutional arrangements in East Germany, i.e. the adoption of the Western educational system had an especially positive impact on the East, helping to partially close the gap along the integration process.

In the following section we will introduce in the estimation model a variable for residence in 1989, rather than residence in 2014. Since our main interest is the educational systems households were exposed to, we would need information about the place where schooling was completed, rather than current residence. Unfortunately, we do not have this exact information and it is possible that some of the respondents, while currently living in one part of Germany, completed their education in the other part. Therefore, we employ residence in 1989 as a proxy for the region where education was completed. Given the strict division between the two regions and the harsh controls on East-to-West mobility during the Cold War, we assume that an individual living in the East in 1989 had few possibilities to attend school in the West in the previous years.

It could still be the case that some households, despite the rigid system, managed to

\footnotetext{
${ }^{14}$ Please check the following reference about why it is meaningless to conduct significance check on the difference by groups http://www.statalist.org/forums/forum/general-stata-discussion/general/ 1302193-Logit-Probit-how-to-compare-coeficients-between-groups-n-and-m-size

${ }^{15}$ Estimations are also conducted for individual items, but not reported here. They can be seen upon request.
} 
escape from East to West Germany in the years before reunification. If many people studied in the East, but were living in the West in 1989 as a consequence of their escape from the socialist regime, the coefficient estimates for different educational levels in the West would be downward biased (if we believe that the Western educational system improved financial literacy).

Unfortunately, we have no means to control for this possibility, since we have no information about the households before 2014. Our hope is that this option is not affecting too much the results in our sample. Given that, in our sample, only $8.3 \%$ of respondents migrated from East to West between 1989 and 2014 (and, indeed, the mobility variable is always non-significant), we believe that a large ratio of residence mobility before 1989 is also not a concern.

One scenario which might harm our reasoning is that the educational system in the East did not change much after the reunification. In this case, the difference seen above should not be attributed to anything related to the educational system. However, because of the well-known integration process of Germany we tend to exclude this possibility (see as well Fuchs-Schündeln and Masella (2016) for a broader discussion about it). 


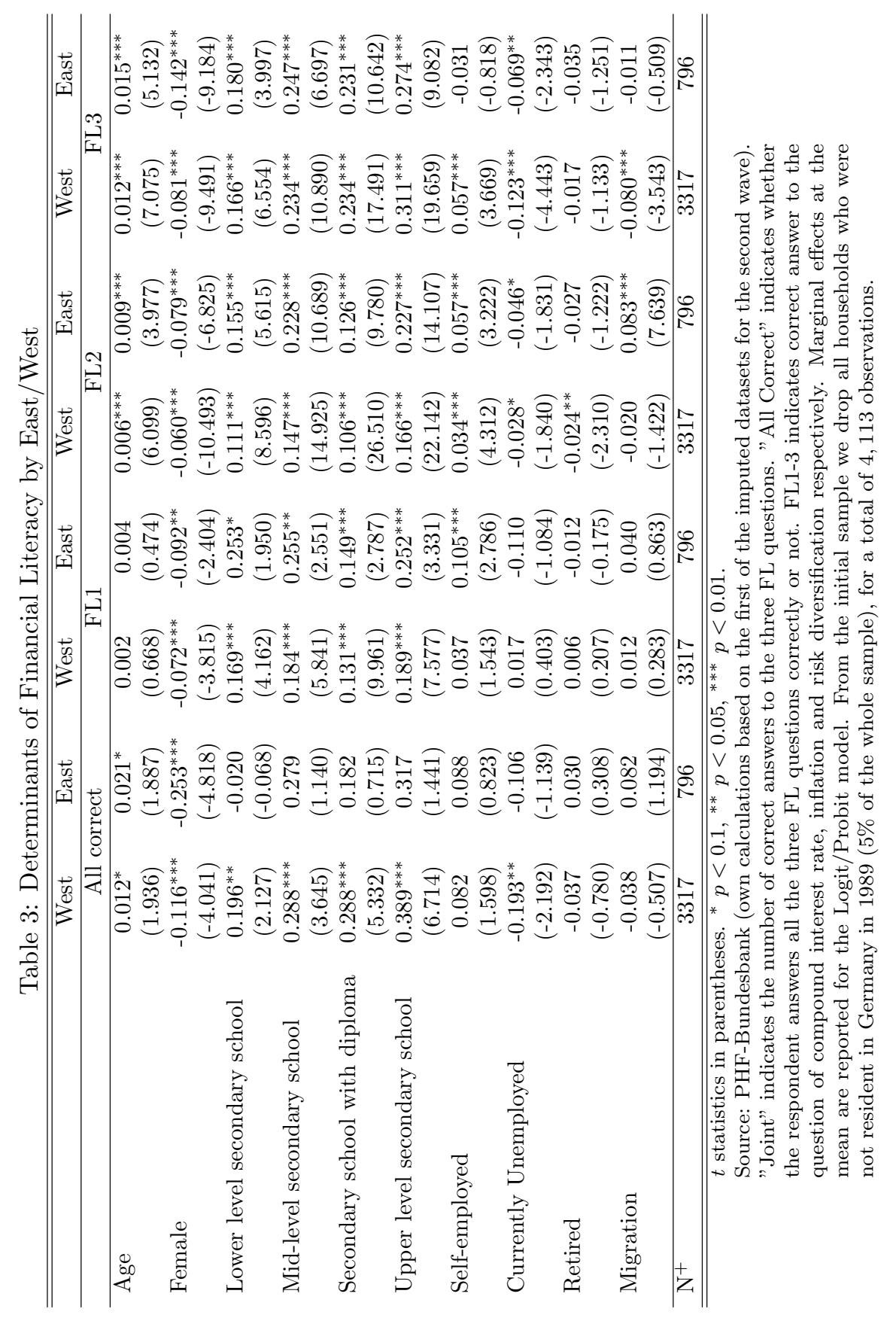




\subsection{Education As a Channel of the Reunification Affecting Finan- cial Literacy: the DID Approach}

As suggested by Bucher-Koenen and Lamla (2014), the division of Germany into the FDR and the GDR and the subsequent fall of the Berlin Wall in 1989 can be considered as an event exogenous to the levels of financial knowledge prior to the division and to unobserved variables at the household levels. The educational system in the GDR rapidly changed after the fall of the Berlin Wall, and all features aiming at creating a socialist personality were eliminated from the system. On the contrary, the educational system in the West did not experience any major changes, following the reunification process. Hence, the Berlin Wall Fall can be taken as a quasi-natural experiment which hugely impacted the East, allowing us to apply a difference-in-differences estimation to further uncover the causal effect of education under the socialist regime on financial literacy. Respondents belonging to cohorts in schooling age were, by law, attending school under either the Western or the socialist system, up to 1989. At the time of the Berlin Wall, while nothing changed for Western households, some individuals in the East had been exposed to socialist education (by different length of time) while others were about to start school in the unified system. Thus, we expect financial literacy of Eastern households to exhibit different patterns over cohorts differently exposed to the socialist educational system, because of the reunification process.

We use households' residence in 1989 to distinguish treatment and control group. The before/after treatment is determined by the birth cohort of the respondent, so that only those who received some education under the communist regime are treated ${ }^{16}$. The estimation equation is as follows:

$$
P\left(Y_{i}=1 \mid \mathbf{X}\right)=\Phi\left(\alpha+\beta X_{i}+\gamma_{1} \text { East }_{i}+\gamma_{2} \text { Treat }_{i}+\delta \text { East }_{s} * \text { Treat }_{i}+e_{i}\right)
$$

where the independent variable $Y_{i}$ is given by the FKP $i$ answering all three financial literacy questions correctly. $X_{i}$ is a set of independent variables as mentioned in section 4.1 , and $\delta$ is the coefficient of interest. East ${ }_{i}$ equals 1 if an individual was resident in the East in 1989, and Treat $_{i}$ equals 1 if an individual is older than a threshold birth cohort, as described later. East $_{i} *$ Treat $_{i}$ identifies the effect of the treatment.

In the first specification, we assume that primary school education is the one with the biggest impact on later-life outcomes, i.e. on our measure of financial literacy. Those people from the East who completed their primary school before 1989 (i.e. when Germany was still a divided country) are expected to exhibit lower levels of financial literacy, as compared to

\footnotetext{
${ }^{16} \mathrm{As}$ it has been argued in section 4.1, we use residence as a proxy for where the respondents obtained their education.
} 
other cohorts in the East and to all the cohorts in the West.

Following Fuchs-Schündeln and Masella (2016), we consider the official end of compulsory primary school at 12 years of age, so that those who are exposed to primary school in the divided Germany are at least 37 years old (or older) at the time of the survey. Hence, we generate a cohort dummy equal to 1 if the age of the FKP at the time of survey is 37 years or older, and equal to zero otherwise. This is the time variable for the treatment in a standard DID model. If the FKP is older than 37 years old in 2014 and was living in the East in 1989, which means the East ${ }_{i} *$ Treat $_{i}$ term equals one, then she is treated by the treatment.

If $\delta$ is significant, being treated by the socialist system has a significant effect on household's financial literacy, and we suggest such effect passes through the different educational system. Two subsequent specifications assume that either high school education or college are critical to individuals' financial literacy, and the threshold is adjusted accordingly for the two cases, i.e. 42 (or older) and 46 (or older) in 2014, respectively. It is worth noting that our specification can only identify the overall effect of exposure to the reunified Germany on financial literacy. Unfortunately, as we do not directly observe the date of birth of the respondents, rather their year of birth, we cannot properly disentangle cohort and educational system effects. We will however provide a series of robustenss checks to prove the validity of our results.

Before the reunification, the educational system in the Eastern part was organized as can be seen in Table 5 in the Appendix. Although the school entry age is quite similar between the two states, the emphasis within systems was posed on different subjects. For example, full employment and the creation of socialist individuals were said to be among the main goals of education in the East, which also had a heavier focus on math and science. This last feature, in principle, could increase households ability to answer the financial literacy items.

Table 4 reports the weighted mean of key variables in control and treatment groups across the two regions. Residence is defined by the region where the respondent lived in 1989. As variables such as retirement are closely related to age, based on which we define the treatment, we do not report summary statistics on those variables. Clearly, the two regions considerably differ from one another, after 40 years of Cold War. The main systematic difference in Table 4 comes from the mean of migration rate, which is over $10 \%$ in the East and around $7 \%$ in the West. By our definition, migration dummy equals to 1 if the respondent's residence differ between 1989 and the time of the interview. 
Table 4: Sample Means by Treatment and Control Groups

\begin{tabular}{lccccc}
\hline \hline & Full & \multicolumn{2}{c}{ West } & \multicolumn{2}{c}{ East } \\
& & Control & Treated & Control & Treated \\
\hline Female & 0.470 & 0.513 & 0.459 & 0.441 & 0.521 \\
Migration & 0.076 & 0.081 & 0.054 & 0.223 & 0.108 \\
Self-employment & 0.079 & 0.062 & 0.079 & 0.059 & 0.077 \\
Unemployed & 0.048 & 0.071 & 0.022 & 0.053 & 0.061 \\
Observations & 3,785 & 352 & 2,739 & 136 & 558 \\
\hline \hline
\end{tabular}

\subsubsection{DID Identification}

Table 5 below presents the results of our DID estimation. Residence in the East in 1989 has a significantly negative effect on financial literacy in all three scenarios. Older residents in the East exhibit, on average, lower financial literacy scores, between $13 \%$ to $20 \%$ points lower than the control group. Such result is robust to controls for age and age squared. The bigger in magnitude and more significant coefficients for the $\delta$ term in column (3) and (4), as compared to (1) and (2), suggest a possibly stronger role of receiving higher education in the East on financial literacy.

When we compare results in Table 5, we see that marginal effects estimated with Probit model are very close to the OLS estimates, which confirms the reliability of our results. One issue of Probit model we need to be aware of is the marginal effects for interaction terms. As Norton et al. (2004) point out, the marginal effects of interaction terms in Probit model depend on other independent variables. As a result, one should get a curve, instead of a point estimate for the marginal effects of the interaction term. In order to compare the results, we report the real marginal effects of the East $*$ Treat $(2)$ in Figure 3 using the command introduced by Norton et al. (2004 $)^{17}$. The negative effects of the treatment on those exposed to the socialist education are still significant.

\subsubsection{Robustness Checks}

The results in Table 5, although supporting our original hypothesis, are potentially biased for different reasons. Hence, in the following, we try and address the main concerns related to out identification strategy, by performing different robustness checks.

\section{- Further Controls}

\footnotetext{
${ }^{17}$ Given that East $*$ Treat $(2)$ was the coefficient with the highest significance and the biggest magnitude we selectively report only the results for its marginal effects. The same analysis was also performed for East $*$ Treat $(1)$ and East $*$ Treat $(3)$ and it is available upon request.
} 
Table 5: Determinants of Financial Literacy: DiD

\begin{tabular}{|c|c|c|c|c|c|c|}
\hline & \multicolumn{2}{|c|}{$>=12$ in 1989} & \multicolumn{2}{|c|}{$>=18$ in 1989} & \multicolumn{2}{|c|}{$>=22$ in 1989} \\
\hline & Probit & OLS & Probit & OLS & Probit & OLS \\
\hline \multirow[t]{2}{*}{ Age } & 0.011 & 0.010 & 0.012 & 0.012 & $0.014^{* *}$ & $0.014^{* *}$ \\
\hline & $(1.208)$ & $(1.220)$ & $(1.469)$ & $(1.604)$ & $(2.065)$ & $(2.147)$ \\
\hline \multirow[t]{2}{*}{ Female } & $-0.145^{* * *}$ & $-0.137^{* * *}$ & $-0.145^{* * *}$ & $-0.137^{* * *}$ & $-0.146^{* * *}$ & $-0.138^{* * *}$ \\
\hline & $(-5.789)$ & $(-5.872)$ & $(-5.798)$ & $(-5.881)$ & $(-5.806)$ & $(-5.898)$ \\
\hline \multirow[t]{2}{*}{ Lower level secondary school } & $0.170^{*}$ & $0.170^{* *}$ & $0.171^{* *}$ & $0.170^{* *}$ & $0.168^{*}$ & $0.169^{* *}$ \\
\hline & $(1.955)$ & $(2.039)$ & $(1.975)$ & $(2.058)$ & $(1.941)$ & $(2.031)$ \\
\hline \multirow[t]{2}{*}{ Mid-level secondary school } & $0.308^{* * *}$ & $0.339^{* * *}$ & $0.309^{* * *}$ & $0.339^{* * *}$ & $0.306^{* * *}$ & $0.337^{* * *}$ \\
\hline & $(4.305)$ & $(4.041)$ & $(4.343)$ & $(4.074)$ & $(4.286)$ & $(4.037)$ \\
\hline \multirow[t]{2}{*}{ Secondary school with diploma } & $0.283^{* * *}$ & $0.357^{* * *}$ & $0.285^{* * *}$ & $0.360^{* * *}$ & $0.282^{* * *}$ & $0.356^{* * *}$ \\
\hline & $(5.379)$ & $(4.000)$ & $(5.493)$ & $(4.066)$ & $(5.341)$ & $(4.004)$ \\
\hline \multirow[t]{2}{*}{ Upper level secondary school } & $0.385^{* * *}$ & $0.452^{* * *}$ & $0.386^{* * *}$ & $0.453^{* * *}$ & $0.383^{* * *}$ & $0.450^{* * *}$ \\
\hline & $(7.001)$ & $(5.380)$ & $(7.083)$ & $(5.439)$ & $(6.949)$ & $(5.382)$ \\
\hline \multirow[t]{2}{*}{ Self-employed } & $0.086^{*}$ & $0.072^{*}$ & $0.085^{*}$ & $0.072^{*}$ & $0.085^{*}$ & $0.072^{*}$ \\
\hline & $(1.845)$ & $(1.925)$ & $(1.865)$ & $(1.942)$ & $(1.837)$ & $(1.920)$ \\
\hline \multirow[t]{2}{*}{ Currently Unemployed } & $-0.150^{* *}$ & $-0.141^{* *}$ & $-0.150^{* *}$ & $-0.140^{* *}$ & $-0.153^{* *}$ & $-0.143^{* *}$ \\
\hline & $(-2.332)$ & $(-2.376)$ & $(-2.307)$ & $(-2.345)$ & $(-2.362)$ & $(-2.392)$ \\
\hline \multirow[t]{2}{*}{ Retirement } & -0.026 & -0.022 & -0.027 & -0.024 & -0.030 & -0.027 \\
\hline & $(-0.598)$ & $(-0.547)$ & $(-0.638)$ & $(-0.602)$ & $(-0.712)$ & $(-0.658)$ \\
\hline \multirow[t]{2}{*}{ Migration between East/West } & -0.006 & -0.008 & -0.011 & -0.012 & -0.010 & -0.011 \\
\hline & $(-0.131)$ & $(-0.172)$ & $(-0.227)$ & $(-0.271)$ & $(-0.194)$ & $(-0.241)$ \\
\hline \multirow[t]{2}{*}{ East } & 0.054 & 0.048 & 0.077 & 0.071 & 0.030 & 0.031 \\
\hline & $(0.895)$ & $(0.860)$ & $(1.493)$ & $(1.489)$ & $(0.601)$ & $(0.706)$ \\
\hline \multirow[t]{2}{*}{ Treat $(1)$} & 0.065 & 0.058 & & & & \\
\hline & $(0.805)$ & $(0.836)$ & & & & \\
\hline \multirow[t]{2}{*}{ East*Treat(1) } & $-0.144^{*}$ & $-0.126^{* *}$ & & & & \\
\hline & $(-1.937)$ & $(-1.979)$ & & & & \\
\hline \multirow[t]{2}{*}{ Treat $(2)$} & & & 0.065 & 0.049 & & \\
\hline & & & $(0.908)$ & $(0.790)$ & & \\
\hline \multirow[t]{2}{*}{ East*Treat $(2)$} & & & $-0.202^{* * *}$ & $-0.177^{* * *}$ & & \\
\hline & & & $(-2.974)$ & $(-3.102)$ & & \\
\hline \multirow[t]{2}{*}{ Treat(3) } & & & & & 0.023 & 0.018 \\
\hline & & & & & $(0.386)$ & $(0.345)$ \\
\hline \multirow[t]{2}{*}{ East*Treat(3) } & & & & & $-0.139^{* *}$ & $-0.130^{* *}$ \\
\hline & & & & & $(-2.132)$ & $(-2.350)$ \\
\hline $\mathrm{N}$ & 4111 & 4111 & 4111 & 4111 & 4111 & 4111 \\
\hline r2 & & 0.119 & & 0.122 & & 0.120 \\
\hline
\end{tabular}

t statistics in parentheses. ${ }^{*} p<0.1,{ }^{* *} p<0.05,{ }^{* * *} p<0.01$.

Source: PHF-Bundesbank (own calculations based on the first of the imputed datasets for the second wave). Marginal effects from Probit estimation are presented. Results are weighted. Treat(1) is a dummy equal to 1 if the FKP is 37 years old (or older) at the time of the survey. Treat(2) and Treat(3) equal one if the FKP is 42 or 46 years old (or older), respectively. 
Figure 3: Real Marginal Effects of East $*$ Treat $(2)$ Term on Financial Literacy Interaction Effects after Probit

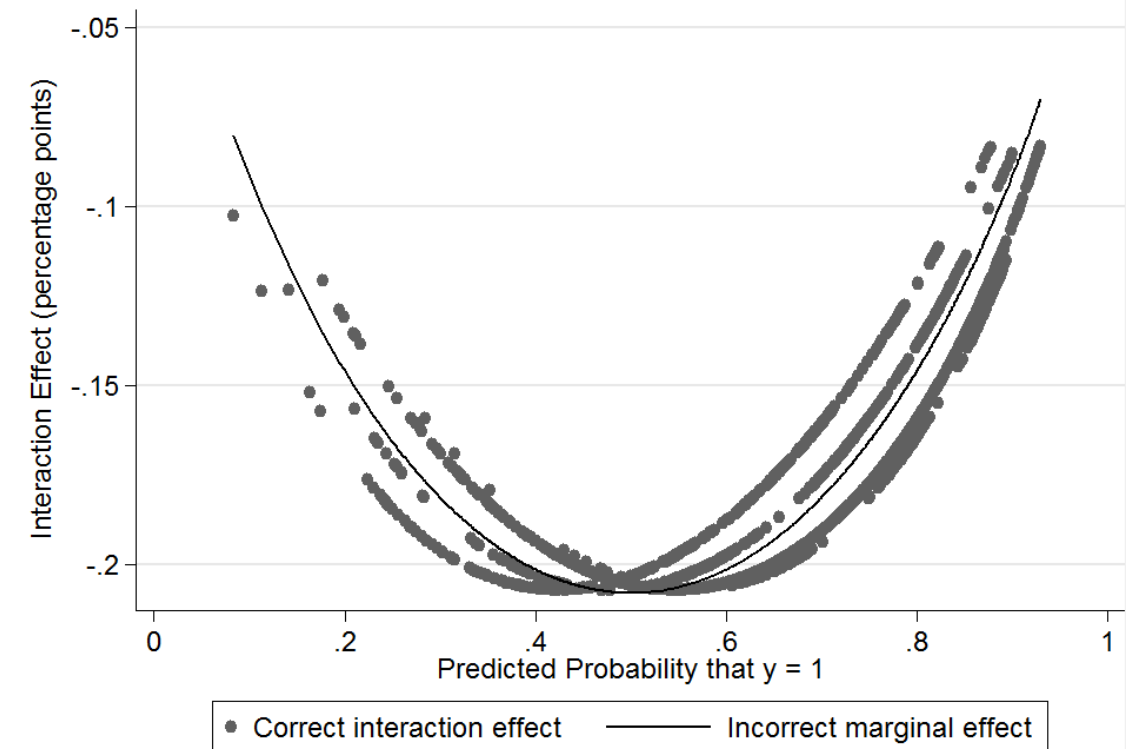

Source: PHF-Bundesbank (own calculations based on the first of the imputed datasets for the second wave). We report marginal effects for the Probit model for those individuals who were at least 18 in 1989 . Results are weighted. Treat(2) is a dummy equal to 1 if the FKP is 42 years old (or older) at the time of the survey. 
One source of bias may arise from omitted variables, especially family characteristics. The idea is that family-specific characteristics can affect an individual's financial knowledge through spillover effects within the family. Hence, we introduce further controls in the DID estimation the marital status of the FKP and the number of kids per households. Results are presented in the first two columns of each of the three DID specifications in Table 6 We can observe that results stay at most unchanged and neither kids nor married have significant impacts on financial literacy.

One further concern in the benchmark analysis of Table 5 is that we do not control for cohort-specific effects. If cohorts in Germany inherently differ from one another (and they differ between East and West), we would systematically be capturing the effect of belonging to a specific birth cohort, rather than the treatment of socialist education. It could be, for example, that individuals from specific cohorts have an innate ability for financial literacy, independent from the education received. Clearly, we cannot include a set of cohort-specific fixed effects, as these would be perfectly collinear with our DID coefficient. We do control, however, for groups of cohorts. In Table 6 in the third column of each specification (columns (3), (7), (11)) we group 6 cohorts together (i.e. households between 24 and 29 years of age, between 30 and 36 , etc.), whereas in column (4), (8) and (12) we introduce a dummy for groups of three cohorts together (i.e. households between 24 and 27 years of age and so on), in order to capture even more fine levels of cohort effects. Results are consistent with those presented in the section above, with the sole difference of the first specification, losing here its significance. 


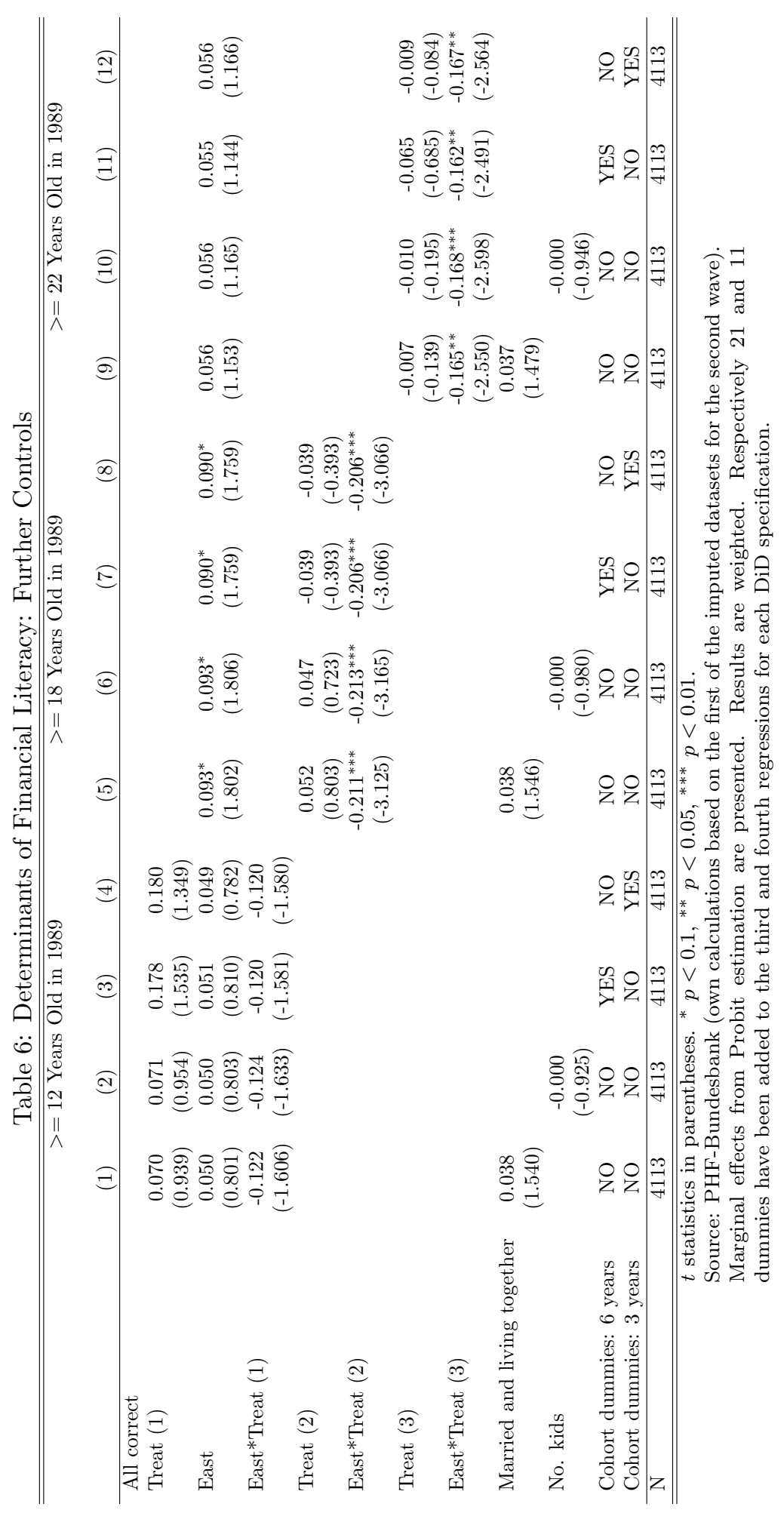


Given our assumption that education is the main channel through which the reunification process affects financial literacy, we should expect an increased proportion of correctly answered questions for the younger cohorts in the East. The younger the Eastern respondent, the shorter her exposure to socialist education and the longer to the reformed system after the reunification. Hence, we would expect to observe a non-negative interaction of East with younger cohorts. We employ once more the Probit specification, as follows:

$$
P\left(Y_{i c}=1 \mid \mathbf{X}\right)=\Phi\left(\alpha+\beta X_{i}+\gamma_{1} \text { East }_{i c}+\sum_{c=1}^{50} \gamma_{c} \text { Treat }_{c}+\sum_{c=1}^{50} \delta_{c} \text { East }_{i} * \text { Treat }_{c}+e_{i c}\right)
$$

We consider cohorts aged 1 to 50 in 1989, i.e. aged 26 to 75 years old in 2014. Because of the difficulty in interpreting the coefficients of interaction terms in Probit model, as mentioned above, we also estimate the marginal effects using OLS specification.

Figure 4 presents the estimation of $\delta_{c}$ from both the Probit and OLS model.The Kernelweighted local polynomial smoothing in the lower panel shows a decreasing trend of the coefficients over age, as expected. Despite the effects being non significant for most of the interaction terms, we clearly see the coefficients close to zero for all cohorts up to 10/12 years of age in 1989, whereas it turns negative for subsequent cohorts. Again, this is supporting our idea that individuals who were not exposed at all to the socialist system (because too young at the time of the reunification) do not experience any type of effect, as captured by the interaction DID terms. The decreasing trend is robust to wider bins of cohorts and to a dependent variable that equals the number of correct answers (Figure 6 in the Appendix). 


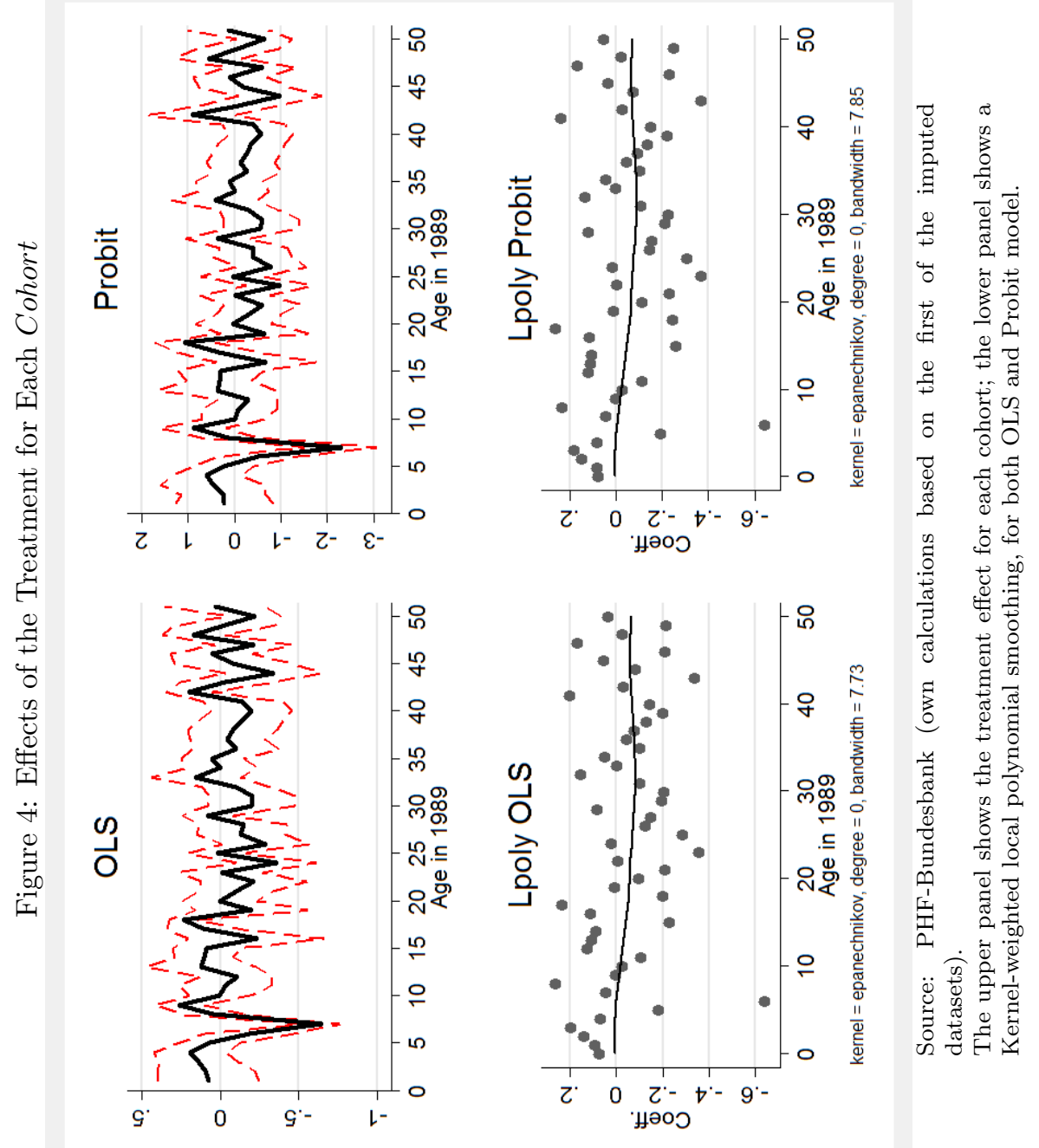


As the cohort effect is one of the major sources for possible bias in our results, we implement the DID estimation on different sub-samples restricted by different age groups. First, we drop from our pool of observations those individuals who either were too young in 1989 to get any education (i.e. households 7 years old at the time of reunification), either were too old and completed schooling before the division of Germany was implemented (i.e. households already 50 years old in 1989 and, hence, 11 years old in 1950). Table 7 confirms, even in the reduced sample, a consistently negative effects of the treatment on financial literacy of individuals 32 to 75 years old in 2014. The significant coefficients in column 2 suggest once more an important role played by higher education, as compared to other educational levels.

Table 8 reports results using further restricted samples, in order to quantify the effects of exposure to different levels of socialist education. In the first three columns, the sample is restricted to observations who were 32 to 49 years old in 2014, i.e. who were 7 to 24 years old in 1989. The negative effect of being exposed to high school remains significant, as shown by column (2). In column (4) to (6), the sample is restricted to households who could only be exposed to the socialist primary school, high school and university, respectively. Being exposed to the socialist high school still has significantly negative effects on the Eastern households' financial literacy.

An analysis of heterogenous effects across different educational level achieved, see Table 9, reveals some interesting patterns. So far we only used birth cohorts and residence in 1989 as determinants of where education was completed. While this is likely to measure actual education achieved when we consider primary education, compulsory both in the East and in the West, it does not necessarily hold true for other levels of education, which might never be reached by many of the households. Hence, we look at our DID estimation strategy for subgroups of the population which completed, respectively, Hauptschule, Realschule, Oberschule and Gymnasium. Interestingly, the effect of treatment is still visible and quite sizeable for individuals who completed Hauptschule and Realschule, above $20 \%$ points in most cases. On the other hand, the effect of completing Gymnasium in the socialist system is not statistically significant. Hence, the effect of the different educational system on financial literacy emerges only for lower levels of education, and not as an overall effect. 


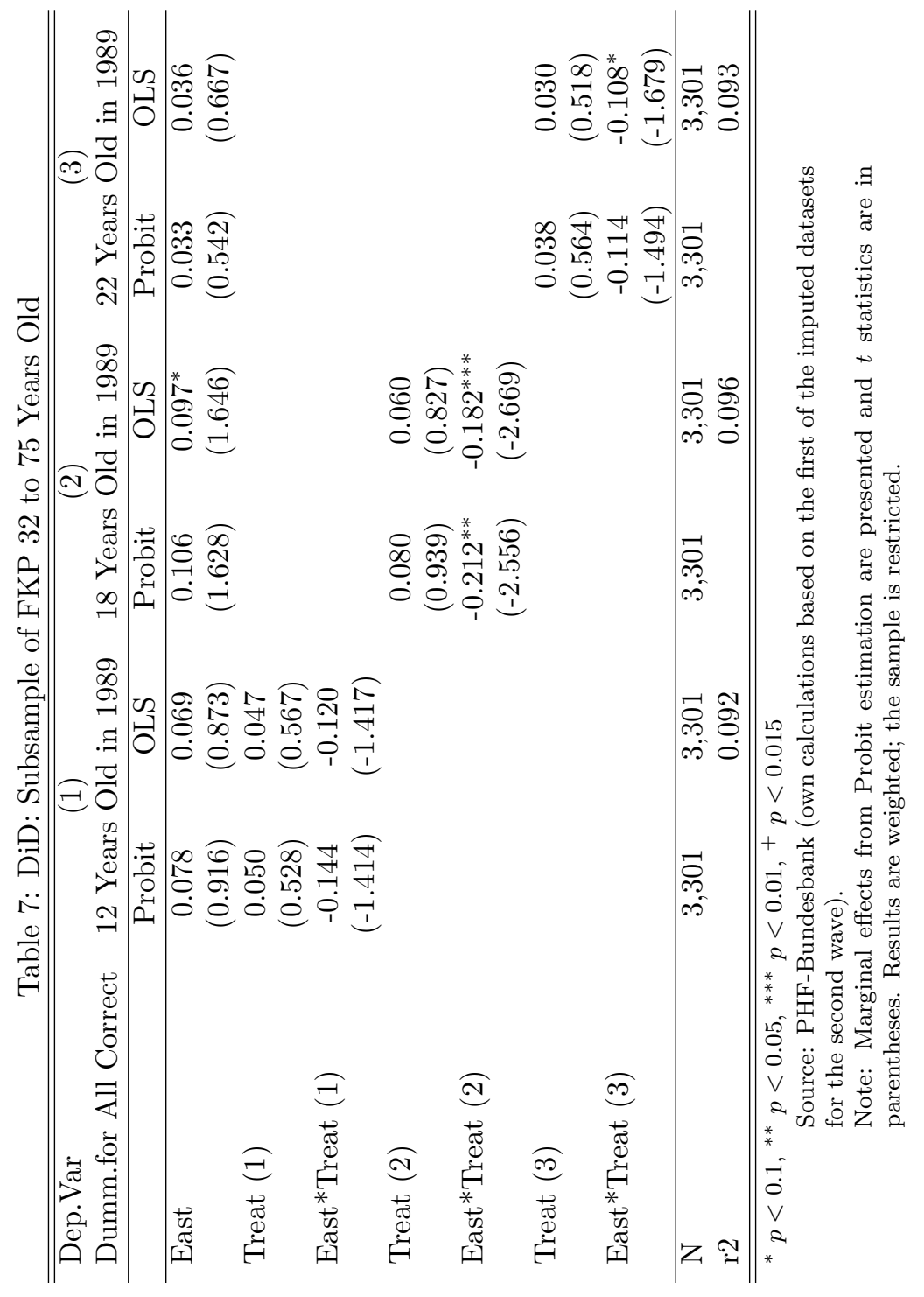


Table 8: DID on restricted age groups

\begin{tabular}{|c|c|c|c|c|c|c|}
\hline Age in 2014 & $\begin{array}{c}(1) \\
{[32,49]}\end{array}$ & $\begin{array}{c}(2) \\
{[32,49]}\end{array}$ & $\begin{array}{c}(3) \\
{[32,49]}\end{array}$ & $\begin{array}{c}(4) \\
{[32,41]}\end{array}$ & $\begin{array}{c}(5) \\
{[38,47]}\end{array}$ & $\begin{array}{c}(6) \\
{[44,49]}\end{array}$ \\
\hline East & $\begin{array}{c}0.065 \\
(0.837)\end{array}$ & $\begin{array}{c}0.093 \\
(1.552)\end{array}$ & $\begin{array}{c}0.033 \\
(0.605)\end{array}$ & $\begin{array}{c}0.063 \\
(0.815)\end{array}$ & $\begin{array}{c}0.085 \\
(0.929)\end{array}$ & $\begin{array}{c}-0.179 \\
(-1.306)\end{array}$ \\
\hline Treat(1) & $\begin{array}{c}0.075 \\
(0.596)\end{array}$ & & & $\begin{array}{c}0.024 \\
(0.175)\end{array}$ & & \\
\hline East*Treat(1) & $\begin{array}{c}-0.093 \\
(-0.964)\end{array}$ & & & $\begin{array}{c}0.020 \\
(0.156)\end{array}$ & & \\
\hline Treat(2) & & $\begin{array}{c}0.026 \\
(0.299)\end{array}$ & & & $\begin{array}{c}-0.016 \\
(-0.146)\end{array}$ & \\
\hline East*Treat(2) & & $\begin{array}{c}-0.258^{* * *} \\
(-2.685)\end{array}$ & & & $\begin{array}{c}-0.266^{* *} \\
(-2.027)\end{array}$ & \\
\hline Treat(3) & & & $\begin{array}{c}-0.002 \\
(-0.019)\end{array}$ & & & $\begin{array}{c}-0.094 \\
(-0.729)\end{array}$ \\
\hline East*Treat(3) & & & $\begin{array}{c}-0.169 \\
(-1.479)\end{array}$ & & & $\begin{array}{c}0.039 \\
(0.231)\end{array}$ \\
\hline $\mathrm{N}$ & 1,060 & 1,060 & 1,060 & 441 & 608 & 487 \\
\hline $\mathrm{r} 2$ & 0.070 & 0.081 & 0.072 & 0.091 & 0.108 & 0.167 \\
\hline
\end{tabular}

$t$ statistics are in parentheses;

${ }^{*} p<0.1,{ }^{* *} p<0.05,{ }^{* * *} p<0.01,+p<0.015$

Source: PHF-Bundesbank (own calculations based on the first of the imputed datasets for the second wave).

Results are weighted and the sample is restricted to the specified age groups. 


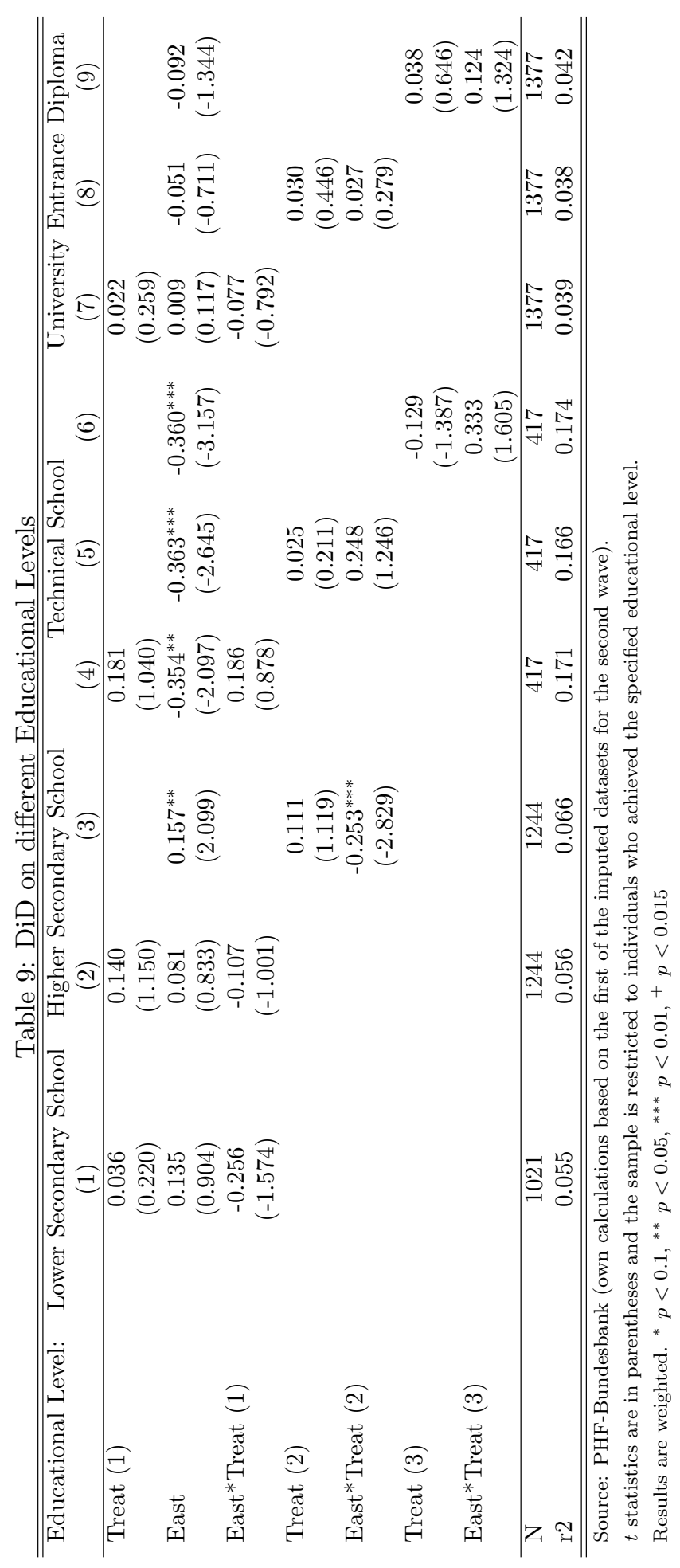


As other analysis similar to ours (see, for example, Fuchs-Schündeln and Masella (2016), we have a problem in our identification strategy given by the lack of information on households mobility before 1989. It is well known that, at least up to the construction of the Berlin wall in 1961 (and possibly even at later stages), many Eastern households escaped from the regions under the control of the Soviet Union and moved to the West of Germany. These households appear in our data as FDR residents in 1989. If the households who moved from East to West before 1989 are intrinsically different from the ones who stayed in the East, and hence their financial literacy is intrinsically different, then the assumptions underlying our identification strategy do not hold anymore.

Unfortunately, we cannot control for their presence in the sample. What we do, though, is to exclude the observations from our analysis the FKP who moved between 1989 and 2014, relying on the idea that they may share characteristics similar to households who experienced regional mobility before the reunification. Results, presented in Table 10 , confirm our previous findings, so that households who migrated between East and West do not seem to present different characteristics from the rest of the sample.

Table 10: DiD: Subsample without East-West migrated Households

\begin{tabular}{|c|c|c|c|c|c|c|}
\hline \multirow{3}{*}{ Treat (1) } & \multicolumn{2}{|c|}{ "12 Years Old in 1989} & \multicolumn{2}{|c|}{ 18 Years Old in 1989} & \multicolumn{2}{|c|}{22 Years Old in 1989} \\
\hline & Probit & OLS & Probit & OLS Probit & OLS & \\
\hline & $\begin{array}{c}0.099 \\
(0.500)\end{array}$ & $\begin{array}{c}0.034 \\
(0.484)\end{array}$ & & & & \\
\hline East & $\begin{array}{c}0.003 \\
(0.016)\end{array}$ & $\begin{array}{c}-0.000 \\
(-0.008)\end{array}$ & $\begin{array}{c}0.184 \\
(1.192)\end{array}$ & $\begin{array}{c}0.062 \\
(1.174)\end{array}$ & $\begin{array}{c}0.081 \\
(0.584)\end{array}$ & $\begin{array}{c}0.028 \\
(0.599)\end{array}$ \\
\hline East*Treat (1) & $\begin{array}{c}-0.143 \\
(-0.704)\end{array}$ & $\begin{array}{c}-0.050 \\
(-0.690)\end{array}$ & & & & \\
\hline Treat $(2)$ & & & $\begin{array}{c}0.112 \\
(0.654)\end{array}$ & $\begin{array}{c}0.033 \\
(0.563)\end{array}$ & & \\
\hline East ${ }^{*}$ Treat $(2)$ & & & $\begin{array}{c}-0.431^{* *} \\
(-2.375)\end{array}$ & $\begin{array}{c}-0.150^{* *} \\
(-2.403)\end{array}$ & & \\
\hline Treat(3) & & & & & $\begin{array}{c}-0.049 \\
(-0.338)\end{array}$ & $\begin{array}{c}-0.017 \\
(-0.349)\end{array}$ \\
\hline East*Treat (3) & & & & & $\begin{array}{l}-0.305^{*} \\
(-1.780)\end{array}$ & $\begin{array}{l}-0.110^{*} \\
(-1.856)\end{array}$ \\
\hline $\mathrm{N}$ & 3799 & 3799 & 3799 & 3799 & 3799 & 3799 \\
\hline $\mathrm{r} 2$ & & 0.082 & & 0.085 & & 0.084 \\
\hline
\end{tabular}

Source: PHF-Bundesbank (own calculations based on the first of the imputed datasets for the second wave). $t$ statistics are in parentheses and the sample is restricted to individuals who did not change residence between 1989 and 2014. Results are weighted. ${ }^{*} p<0.1,{ }^{* *} p<0.05,{ }^{* * *} p<0.01,+p<0.015$

\section{- Clustered Standard Errors}

Another limitation in our dataset is given by the fact that we do not have precise in- 
formation on the region where the respondents live, due to privacy issues. Given the high heterogeneity of economic outcomes across German regions, this can be a serious omitted variable problem in our analysis. The Bundesbank, however, provided us with anonymous indicators used in the sampling design stage to representatively classify households according to whether they live in large cities, small municipalities, wealthy small municipalities, wealthy street sections or other street sections. Basically, households having the same value of the indicators are located nearby.

In order to account for the possibility that households living nearby are characterized by similar financial literacy patterns, we cluster the errors in our estimation process according to this indicator. All our results are replicated by clustering standard errors at the level of this anonymous geographical indicator, the more granular information we have about household residence in Germany. Results, available upon request, remain unchanged.

\section{Conclusion}

In this study, we explore the determinants of financial literacy in Germany, focusing especially on the existing gap in financial knowledge between the East and the West of the country. Consistently with the literature, we find that age and gender of the individuals highly correlate with our index of financial literacy. However, education, regardless of the level, is the factor with stronger significant effects in both regions.

It is well known that East and West Germany experienced a quite divergent political and economic history during the Cold War, and such different history has hugely influenced the current development of the two regions in a wide variety of areas. Our hypothesis is that exposure to the socialist educational system negatively affected the financial literacy accumulation process in East Germany. By taking advantage of the event of reunification in 1989 and exploiting it as a "natural experiment", we explore this hypothesis and analyze the role of institutional changes, more specifically, changes in the educational system, in shaping the financial literacy of German households. Despite some data limitation which does not allow us to clearly disentangle cohort effects from institutional effects, we do find evidence that the longer an Eastern household had been exposed to socialist education, the lower her financial literacy. Evidence seems to point at a particularly important role of high school education in the former GDR in driving down financial literacy scores in the current period.

The validity of our difference-in-differences estimates relies on a series of assumptions which, in some cases, we are not able to test. The main drawback of our identification strat- 
egy is the impossibility of verifying the pre-treatment parallel trend assumption between treatment and control group. Since we have no information collected before 1989 about financial literacy and other households characteristics, it is difficult to validate this assumption. We rely, though, on many other papers which use the reunification as a quasi-natural experiment and share our same issues.

Hence, we conclude that being exposed to socialist education lowered current-time financial literacy of German households, possibly because of the time in school devoted to socialist ideology and anti-capitalistic values. Our study sheds light on the role of education system on the accumulation of financial literacy, but more studies are required to understand the accumulation process further. 


\section{Appendices}

Table A1: Missing and Imputed Observations for Key Variables

\begin{tabular}{lc}
\hline \hline \multicolumn{1}{c}{ Description } & No. of missing answers \\
\hline Inflation question & 0 \\
Interest rate question & 0 \\
Risk-diversification question & 0 \\
Employment status & 6 \\
Number of children & 6 \\
Residence in 1989 & 6 \\
Country of birth & 0 \\
Region of current residence & 0 \\
Age & 0 \\
Married & 2 \\
Education & 3 \\
Gender & 0 \\
\hline
\end{tabular}

Source: P $\overline{\overline{\text { HF-Bundesbank (own calculations based on the first of the imputed }}}$ datasets. The number of missing values, i.e. the imputed information, refers to the second wave, 4, 461 observations in total. 
Table A2: Aggregated Financial Literacy over Other Demographic Characteristics

\begin{tabular}{|c|c|c|c|c|}
\hline & \multicolumn{2}{|c|}{ West } & \multicolumn{2}{|r|}{ East } \\
\hline & All Correct & No. of Obs. & All Correct & No. of Obs. \\
\hline $\begin{array}{l}\text { Lower-level secondary school } \\
\text { (Hauptschule) }\end{array}$ & $50 \%$ & 863 & $36 \%$ & $\overline{15} 8$ \\
\hline $\begin{array}{l}\text { Mid-level secondary school } \\
\text { (Realschule) }\end{array}$ & $63 \%$ & 908 & $67 \%$ & 336 \\
\hline Oberschule & $61 \%$ & 366 & $69 \%$ & 51 \\
\hline Gymnasium & $80 \%$ & 1,133 & $77 \%$ & 244 \\
\hline Other Education & $22 \%$ & 40 & $44 \%$ & 7 \\
\hline Male & $67 \%$ & 1,957 & $72 \%$ & 423 \\
\hline Female & $56 \%$ & 1,360 & $48 \%$ & 373 \\
\hline Self-employed & $77 \%$ & 314 & $78 \%$ & 52 \\
\hline Not self-employed & $60 \%$ & 3,003 & $59 \%$ & 744 \\
\hline Unemployed & $38 \%$ & 86 & $52 \%$ & 54 \\
\hline Retired & $54 \%$ & 1,264 & $46 \%$ & 327 \\
\hline
\end{tabular}

Table A3: Summary of Key Variables

\begin{tabular}{lcccc}
\hline \hline & & & & \\
& Mean & Std. & Min & Max \\
\hline All questions correct & 0.63 & 0.016 & 0 & 1 \\
FL1 & 0.86 & 0.011 & 0 & 1 \\
FL2 & 0.88 & 0.011 & 0 & 1 \\
FL3 & 0.72 & 0.016 & 0 & 1 \\
Current residence & 0.22 & 0.029 & 0 & 1 \\
Residence in 1989 & 0.20 & 0.025 & 0 & 1 \\
Age & 52,46 & 0.441 & 18 & 90 \\
Female & 0.47 & 0.013 & 0 & 1 \\
Self-employed & 0.08 & 0.007 & 0 & 1 \\
Unemployed & 0.04 & 0.004 & 0 & 1 \\
Retired & 0.35 & 0.012 & 0 & 1 \\
East- West migration & 0.08 & 0.012 & 0 & 1 \\
Hauptschule & 0.39 & 0.014 & 0 & 1 \\
Realschule & 0.29 & 0.012 & 0 & 1 \\
Oberschule & 0.08 & 0.006 & 0 & 1 \\
Gymnasium & 0.22 & 0.011 & 0 & 1 \\
No education & 0.02 & 0.004 & 0 & 1 \\
\hline$N$ & 4113 & & & \\
\hline
\end{tabular}

Source: P $\overline{\overline{H F-B u n d e s b a n k ~(o w n ~ c a l c u l a t i o n s ~ b a s e d ~ o n ~ t h e ~ f i r s t ~ o f ~ t h e ~}}$ imputed datasets).

Wave 2, 4,113 observations; households who where not in Germany in 1989 have been dropped. Results are weighted. 
Table A4: Financial Literacy Determinants: all Regressors

\begin{tabular}{|c|c|c|}
\hline & $\begin{array}{c}\text { (Probit) } \\
\text { All correct }\end{array}$ & $\begin{array}{c}\text { (OLS) } \\
\text { All correct }\end{array}$ \\
\hline East (d) & $\begin{array}{c}-0.017 \\
(-0.546)\end{array}$ & $\begin{array}{c}-0.017 \\
(-0.586)\end{array}$ \\
\hline Age & $\begin{array}{l}0.009^{*} \\
(1.717)\end{array}$ & $\begin{array}{l}0.008^{*} \\
(1.689)\end{array}$ \\
\hline Age squared & $\begin{array}{l}-0.000^{*} \\
(-1.869)\end{array}$ & $\begin{array}{l}-0.000^{*} \\
(-1.826)\end{array}$ \\
\hline Married and living together (d) & $\begin{array}{c}0.002 \\
(0.059)\end{array}$ & $\begin{array}{c}0.002 \\
(0.068)\end{array}$ \\
\hline Female (d) & $\begin{array}{c}-0.124^{* * *} \\
(-4.807)\end{array}$ & $\begin{array}{c}-0.115^{* * *} \\
(-4.791)\end{array}$ \\
\hline Lower level secondary school (d) & $\begin{array}{c}0.138 \\
(1.498)\end{array}$ & $\begin{array}{c}0.139 \\
(1.602)\end{array}$ \\
\hline Mid-level secondary school (d) & $\begin{array}{c}0.248^{* * *} \\
(3.070)\end{array}$ & $\begin{array}{c}0.271^{* * * *} \\
(3.079)\end{array}$ \\
\hline Secondary school with diploma (d) & $\begin{array}{c}0.222^{* * * *} \\
(3.203)\end{array}$ & $\begin{array}{c}0.264^{* * *} \\
(2.840)\end{array}$ \\
\hline Upper level secondary school (d) & $\begin{array}{c}0.316^{* * * *} \\
(4.672)\end{array}$ & $\begin{array}{c}0.349^{* * * *} \\
(3.928)\end{array}$ \\
\hline Investment Behavior Risk Preference & $\begin{array}{l}-0.000 \\
(-0.012)\end{array}$ & $\begin{array}{c}0.001 \\
(0.083)\end{array}$ \\
\hline Self-assessment: Risk & $\begin{array}{c}-0.000 \\
(-0.064)\end{array}$ & $\begin{array}{c}0.000 \\
(0.040)\end{array}$ \\
\hline Self-assessment: Trust & $\begin{array}{c}-0.001 \\
(-0.085)\end{array}$ & $\begin{array}{c}-0.000 \\
(-0.049)\end{array}$ \\
\hline Self-assessment: Patience & $\begin{array}{c}-0.004 \\
(-0.756)\end{array}$ & $\begin{array}{c}-0.003 \\
(-0.693)\end{array}$ \\
\hline Regular Saving (d) & $\begin{array}{c}0.043 \\
(1.485)\end{array}$ & $\begin{array}{c}0.041 \\
(1.526)\end{array}$ \\
\hline Log income & $\begin{array}{l}0.062^{* *} \\
(2.227)\end{array}$ & $\begin{array}{l}0.052^{* *} \\
(2.117)\end{array}$ \\
\hline Self-employment Income (d) & $\begin{array}{l}-0.084 \\
(-1.265)\end{array}$ & $\begin{array}{c}-0.061 \\
(-1.128)\end{array}$ \\
\hline Saving for Funds & $\begin{array}{c}0.009 \\
(1.101)\end{array}$ & $\begin{array}{c}0.007 \\
(1.039)\end{array}$ \\
\hline Income from Financial Assets (d) & $\begin{array}{c}0.091^{* * *} \\
(3.188)\end{array}$ & $\begin{array}{c}0.081^{* * *} \\
(3.152)\end{array}$ \\
\hline Application for a Loan/Credit (d) & $\begin{array}{c}0.023 \\
(0.771)\end{array}$ & $\begin{array}{c}0.018 \\
(0.665)\end{array}$ \\
\hline Self-employed $(\mathrm{d})$ & $\begin{array}{c}0.112^{*} \\
(1.739)\end{array}$ & $\begin{array}{c}0.093 \\
(1.540)\end{array}$ \\
\hline Ownership of Private Business (d) & $\begin{array}{c}0.132 \\
(1.512)\end{array}$ & $\begin{array}{c}0.104 \\
(1.545)\end{array}$ \\
\hline Active Role in Management (d) & $\begin{array}{c}-0.086 \\
(-0.749)\end{array}$ & $\begin{array}{c}-0.059 \\
(-0.812)\end{array}$ \\
\hline Current Employment Status & $\begin{array}{c}-0.009 \\
(-1.611)\end{array}$ & $\begin{array}{l}-0.008 \\
(-1.489)\end{array}$ \\
\hline Unemployment Benefits (d) & $\begin{array}{l}-0.045 \\
(-0.813)\end{array}$ & $\begin{array}{c}-0.049 \\
(-0.929)\end{array}$ \\
\hline East- West migration (d) & $\begin{array}{c}0.009 \\
(0.184) \\
\end{array}$ & $\begin{array}{c}0.007 \\
(0.157)\end{array}$ \\
\hline $\begin{array}{l}\text { Observations } \\
R^{2}\end{array}$ & 4111 & $\begin{array}{l}4111 \\
0.139\end{array}$ \\
\hline
\end{tabular}

Source: PHF-Bundesbank (own calculations based on the first of the imputed datasets).

Marginal effects; $t$ statistics in parentheses. Results are weighted and wave two is employed. The variable 'East' refers to residence at the time of the survey. (d) indicates discrete change of dummy variable from 0 to 1 . 
Table A5: East/West Determinants of Financial Literacy: OLS Model

\begin{tabular}{|c|c|c|}
\hline & \multicolumn{2}{|c|}{ All Correct } \\
\hline & West & East \\
\hline \multirow[t]{2}{*}{ Age } & $0.011^{*}$ & $0.018^{* *}$ \\
\hline & $(1.865)$ & $(1.981)$ \\
\hline \multirow[t]{2}{*}{ Female } & $-0.111^{* * *}$ & $-0.220^{* * *}$ \\
\hline & $(-4.091)$ & $(-4.878)$ \\
\hline \multirow[t]{2}{*}{ Lower level secondary school } & $0.203^{* *}$ & -0.042 \\
\hline & $(2.263)$ & $(-0.168)$ \\
\hline \multirow[t]{2}{*}{ Mid-level secondary school } & $0.320^{* * *}$ & 0.253 \\
\hline & $(3.554)$ & $(0.995)$ \\
\hline \multirow[t]{2}{*}{ Secondary school with diploma } & $0.374^{* * *}$ & 0.165 \\
\hline & $(3.926)$ & $(0.609)$ \\
\hline \multirow[t]{2}{*}{ Upper level secondary school } & $0.465^{* * *}$ & 0.301 \\
\hline & $(5.178)$ & $(1.184)$ \\
\hline \multirow[t]{2}{*}{ Self-employed } & $0.072^{*}$ & 0.059 \\
\hline & $(1.705)$ & $(0.810)$ \\
\hline \multirow[t]{2}{*}{ Unemployed } & $-0.183^{* *}$ & -0.090 \\
\hline & $(-2.208)$ & $(-1.172)$ \\
\hline \multirow[t]{2}{*}{ Retired } & -0.033 & 0.026 \\
\hline & $(-0.710)$ & $(0.313)$ \\
\hline \multirow[t]{2}{*}{ East-West migration } & -0.033 & 0.067 \\
\hline & $(-0.489)$ & $(1.185)$ \\
\hline $\mathrm{N}$ & 3317 & 796 \\
\hline $\mathrm{r} 2$ & 0.098 & 0.221 \\
\hline
\end{tabular}

Source: PHF-Bundesbank (own calculations based on the first of the imputed datasets for the second wave).

Marginal effects are presented; $t$ statistics in parentheses. Results are weighted. (d) indicates discrete change of dummy variable from 0 to 1 . 
Figure 5: Educational System in the East before Reunification

\section{Struktur des Schulsystems in der DDR}

(vereinfachte Darstellung)

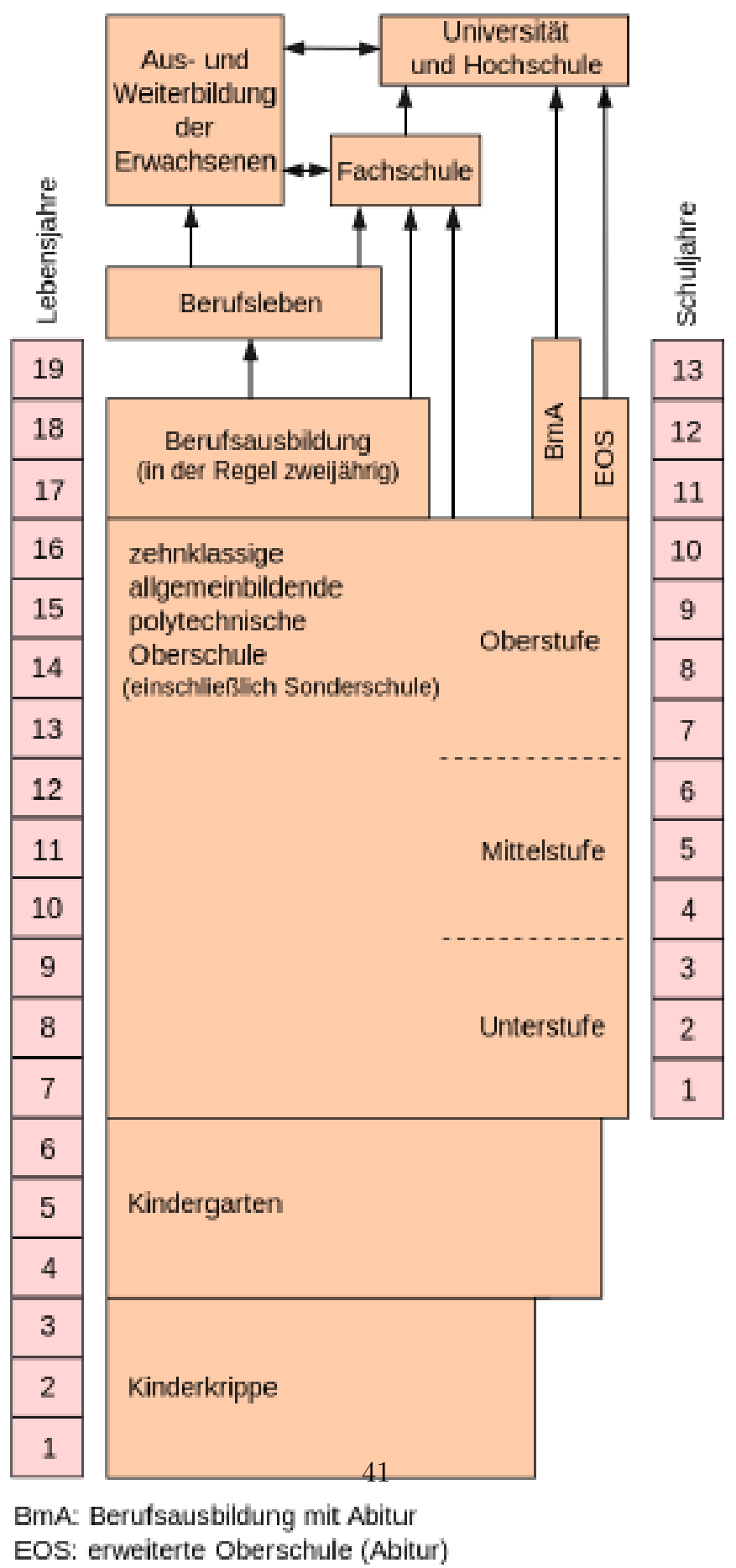

Source: https://de.wikipedia.org/wiki/Bildungssystem_in_der_DDR. 
Figure 6: Effects of the Treatment for Each Cohort: No. of Correct Answers OLS

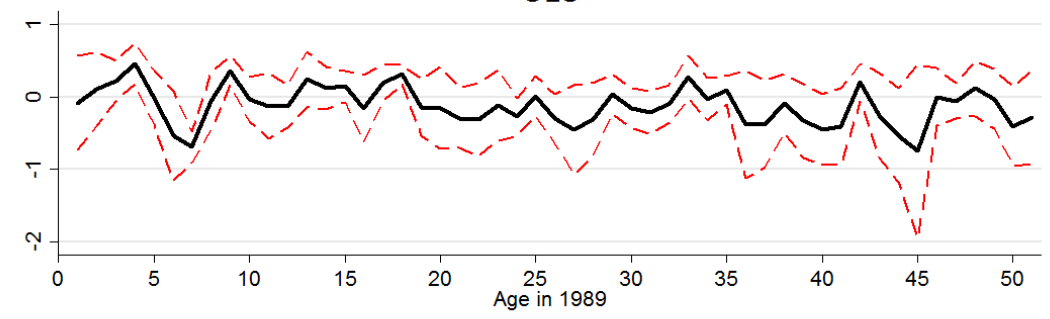

Probit

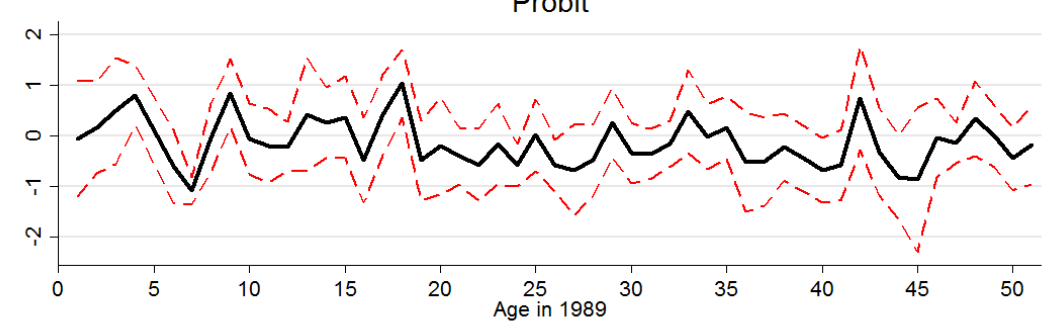

Source: PHF-Bundesbank (own calculations based on the first of the imputed datasets for the second wave).

\section{References}

Agnew, J. R., H. Bateman, and S. Thorp (2013). Financial literacy and retirement planning in Australian. Numeracy 6(11).

Angrist, J. D. and J.-S. Pischke (2008). Mostly harmless econometrics: An empiricist's companion. Princeton University Press.

Behrman, J. R., O. S. Mitchell, C. Soo, and D. Bravo (2012). Financial literacy, schooling, and wealth accumulation. American Economic Review 102(3), 303-304.

Bernheim, B. D. and D. M. Garrett (2003). The effects of financial education in the workplace: Evidence from a survey of households. Journal of Public Economics 87(7), 14871519 .

Bernheim, B. D., D. M. Garrett, and D. M. Maki (2001). Education and saving: The long-term effects of high school financial curriculum mandates. Journal of Public Economics 80(3), 435-465.

Bonin, H. and R. Euwals (2002). Participation behavior of East German women after German unification. 10th International Conference on Panel Data, Berlin, July 5-6, 2002 D1-1, International Conferences on Panel Data. 
Brosig-Koch, J., C. Helbach, A. Ockenfels, and J. Weimann (2011). Still different after all these years: Solidarity behavior in East and West Germany. Journal of Public Economics 95(11), 1373-1376.

Brown, M., C. Henchoz, and T. Spycher (2018). Culture and financial literacy. Journal of Economic Behavior and Organization 150, 62-85.

Brugiavini, A., D. Cavapozzi, M. Padula, and Y. Pettinicchi (2015). Financial education, literacy and investment attitudes. SAFE Working Paper Series 86, Research Center SAFE - Sustainable Architecture for Finance in Europe, Goethe University Frankfurt.

Bucher-Koenen, T. and B. Lamla (2014). The long shadow of socialism: On East-West German differences in financial literacy. MEA discussion paper series 201405, Munich Center for the Economics of Aging (MEA) at the Max Planck Institute for Social Law and Social Policy.

Bucher-Koenen, T. and A. Lusardi (2011). Financial literacy and retirement planning in Germany. Journal of Pension Economics \&3 Finance 10(4), 565-584.

Chen, H. and R. P. Volpe (1998). An analysis of personal financial literacy among college students. Financial Services Review 7(2), 107-128.

Chen, H. and R. P. Volpe (2002). Gender differences in personal financial literacy among college students. Financial Services Review 11(3), 289.

Cole, S., A. Paulson, and G. K. Shastry (2016). High school curriculum and financial outcomes: The impact of mandated personal finance and mathematics courses. Journal of Human Resources 51(3), 656-698.

Delavande, A., S. Rohwedder, and R. Willis (2008, September). Preparation for retirement, financial literacy and cognitive resources. Working Papers wp190, University of Michigan, Michigan Retirement Research Center.

Fornero, E. and C. Monticone (2011). Financial literacy and pension plan participation in Italy. Journal of Pension Economics and Finance 10(04), 547-564.

Fuchs-Schündeln, N. and M. Haliassos (2015). Does product familiarity matter for participation? Technical report, CEPR Discussion Paper No. DP10632.

Fuchs-Schündeln, N. and P. Masella (2016). Long-lasting effects of socialist education. Review of Economics and Statistics 98(3), 428-441.

Fuchs-Schündeln, N. and M. Schündeln (2005). Precautionary savings and self-selection: Evidence from the German reunification "experiment". The Quarterly Journal of Economics 120(3), 1085-1120. 
Fuchs-Schündeln, N. and M. Schündeln (2015). On the endogeneity of political preferences: Evidence from individual experience with democracy. Science 347(6226), 1145-1148.

Gustman, A., T. L. Steinmeier, and N. Tabatabai (2012). Financial knowledge and financial literacy at the household level. American Economic Review 102(3), 309-13.

Hastings, J. S., B. C. Madrian, and W. L. Skimmyhorn (2013). Financial literacy, financial education, and economic outcomes. Annual Review of Economics 5(1), 347-373.

Hung, A., A. M. Parker, and J. Yoong (2009). Defining and measuring financial literacy. Technical report, RAND CorporationWorking Papers - 708.

Jappelli, T. (2010). Economic literacy: An international comparison. The Economic Journal 120(548), F429-F451.

Jappelli, T. and M. Padula (2013). Investment in financial literacy and saving decisions. Journal of Banking \& Finance 37(8), 2779-2792.

Lusardi, A. (2012). Numeracy, financial literacy, and financial decision-making. Technical report, National Bureau of Economic Research.

Lusardi, A., P.-C. Michaud, and O. S. Mitchell (2017). Optimal financial knowledge and wealth inequality. Journal of Political Economy 125(2), 431-477.

Lusardi, A. and O. Mitchell (2007). Financial literacy and retirement planning: New evidence from the Rand American Life Panel. Working Papers wp157, University of Michigan, Michigan Retirement Research Center.

Lusardi, A. and O. S. Mitchell (2008). Planning and financial literacy: How do women fare? American Economic Review 98(2), 413-17.

Lusardi, A. and O. S. Mitchell (2011). Financial literacy and planning: Implications for retirement well-being. Financial Literacy: Implications for Retirement Security and the Financial Marketplace, 17.

Lusardi, A. and O. S. Mitchell (2014). The economic importance of financial literacy: Theory and evidence. Journal of Economic Literature 52(1), 5-44.

Lusardi, A., O. S. Mitchell, and V. Curto (2010). Financial literacy among the young. Journal of Consumer Affairs 44(2), 358-380.

Marsh, H. W., O. Köller, and J. Baumert (2001). Reunification of East and West German school systems: Longitudinal multilevel modeling study of the big-fish-little-pond effect on academic self-concept. American Educational Research Journal 38(2), 321-350. 
Norton, E. C., H. Wang, and C. Ai (2004). Computing interaction effects and standard errors in logit and probit models. Stata Journal 4(2), 154-167.

OECD (2012). OECD/INFE high-level principles on national strategies for financial education. Technical report.

Rooij, M. V., A. Lusardi, and R. Alessie (2011). Financial literacy and stock market participation. Journal of Financial Economics 101(2), 449 - 472.

Rubin, D. B. (1987). Multiple imputation for nonresponse in surveys, Volume 81. John Wiley \& Sons.

Rubin, D. B. (1996). Multiple imputation after 18+ years. Journal of the American statistical Association 91(434), 473-489.

Sekita, S. (2011). Financial literacy and retirement planning in Japan. Journal of Pension Economics and Finance 10(04), 637-656.

Xu, L. and B. Zia (2012). Financial literacy around the world. Policy Research Working Paper $610 \%$. 


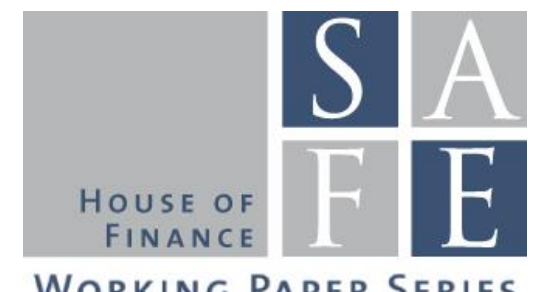

WORKING PAPER SERIES

\section{Recent Issues} No. 216 Stefano Colonnello, Giuliano
Curatola, Alessandro Gioffré

No. 215 Zsuzsa R. Huszár, Zorka Simon

No. 214 Edin Ibrocevic, Matthias Thiemann

No. 213 Klaus Gugler, Michael Weichselbaumer, Christine Zulehner

No. 212 Henning Hesse

No. 211 Thomas Mosk

No. 210 Darien Huang, Christian Schlag, Ivan Shaliastovich, Julian Thimme

No. 209 Eren Gürer, Alfons J. Weichenrieder

No. 208 Roberto Casarin, Michele Costola, Erdem Yenerdag

No. 207 Claes Bäckman, Tobin Hanspal

No. 206 Loriana Pelizzon, Anjan Thakor, Calebe de Roure

No. 205 Horst Entorf, Jia Hou

No. 204 Loriana Pelizzon, Matteo Sottocornola

No. 203 Florian Hett, Felix Schmidt
Pricing Sin Stocks: Ethical Preference vs. Risk Aversion

The Pricing Implications of the Oligopolistic Securities Lending Market: A Beneficial Owner Perspective

All Economic Ideas are Equal, but Some are more Equal than Others: A Differentiated Perspective on Macroprudential Ideas and their Implementation

Effects of Government Spending on Employment: Evidence from Winners and Runners-up in Procurement Auctions

Incentive Effects from Write-down CoCo Bonds: An Empirical Analysis

Bargaining with a Bank

Volatility-of-Volatility Risk

Pro-rich Inflation in Europe: Implications for the Measurement of Inequality

Financial Bridges and Network Communities

The Geography of Alternative Work

P2P Lending versus Banks: Cream Skimming or Bottom Fishing?

Financial Education for the Disadvantaged? A Review

The Impact of Monetary Policy Interventions on the Insurance Industry

Pushing Through or Slacking Off? Heterogeneity in the Reaction to Rank Feedback 